\title{
تربية الأبناء في الإسلام
}

د: طيبة عبد الله محمد أبو البشر 1

المستخلص

$$
\begin{aligned}
& \text { الرسول صلى الله عليه وسلم هو المربي الأول والمثل الأعلى في ذلك علمنا أصول التربية } \\
& \text { الصحيحة يتمثل في العقائد والأخلاق و المبادئ و العادات والتقاليد وحملنا المسئولية لكل } \\
& \text { إنسان (كلكم راع و كلكم مسؤول عن رعيته).ولذا المهام التربوية تقع على المربين بكل } \\
& \text { الطبقات و القيام بالرعاية والتربية و التو جه إلى المثل الأعلى و التمسك بالفضائل. } \\
& \text { الكلمات المتاحية:. تربية ، الابناء ، الاسلام. }
\end{aligned}
$$

1. د: طيبة عبد الله محمد أبو البشر، أستاذ مساعد بكلية الدعوة الإسلامية. 


\section{Abstract}

Prophet Muhammad Peace be upon him is the First Instructor and Ideal mentor in teaching his Followers principles of appropriate Nurturing and education, he a wares them the right beliefs, ethics, principles, norms and traditions, he affirms accountability by sustains personal responsibility. (All of you are shepherds and each shepherd is responsible of his Folk). There Fore, the educational tasks are assigned eventually on the Instructors Whatever their social class; So as to maintain the appropriate care Inspired by noble models and persist to the good behavior.

Keywords:- Nurturing, Children, Islam. 


\section{المقدمة:}

$$
\begin{aligned}
& \text { للتربية اثر واضح في كل مراحل نمو الفرد، وفي هذه المراحل تتغير سلوك الفرد من حال }
\end{aligned}
$$

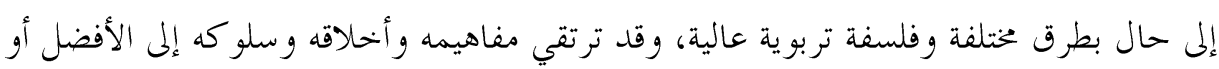

$$
\begin{aligned}
& \text { العكس. وقد تكون مسلماً مؤمناً أو غير ذلك. } \\
& \text { ولهذا جاءت أهمية البحث، من أهم الموضوعات الاجتماعية التي نحن في أمس الحاجة } \\
& \text { إليها لتربية الأبناء على الإيمان والتقوى والتخلق بالأخلاق الفاضلة. } \\
& \text { الإسلامية على أتم وجه. ولابتغاء مرضاة الله عز وجل. } \\
& \text { المنهج المتبع للبحث: اتبع في كتابة هذا الموضوع المنهج التاريخي الوصفي والتجريي تمشياً }
\end{aligned}
$$

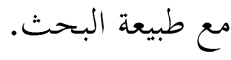

مشكلة البحث: يمكن صياغة البحث في عدة أسئلة، يقوم البحث بالإجابة عنها، وتتمثل في

$$
\begin{aligned}
& \text { ما هي القواعد الأساسية للتربية الإسلامية الصحيحة. } \\
& \text { هل لنماذج التربية الإسلامية اثر في تربية أبناء اليوم. } \\
& \text { الفروض: يمكن عرضه في احتمالات: }
\end{aligned}
$$

جهل الأمهات والآباء عن قو اعد التربية الصحيحة.

التأثير الثقافي و العولمة الحميثة. 


\section{قلة الإيمان و البعد الديني.

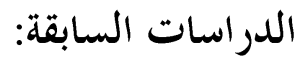

من الدراسات في هذا الموضوع، كتاب بعنوان تربية الطفل في القرآن الكريم والسنة النبوية تأليف سيد احمد جمعة - مكتبة الإيمان - ط 2007م.

وهذا يعتبر من أمهات الكتب الذي بحثت في هذا المحال، بمنهج تاريخي مؤصل بل هناك عدد من المؤلفات ولكنها كل تختلف عن الآخر من أهمية وهدف ومشكلة وخحلاف وهذا البحث و اضح من الخطة بالإضافة إلى ربط الجيل الحاضر بالقدوة الأصيلة.

خطة البحث:

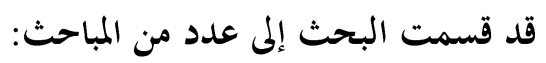

المبحث الأول: المعنى اللغوي والاصطلاحي لكل من التربية، والأبناء، والإسلام.

المبحث الثاني: القواعد الأساسية للتربية الإسلامية.

المبحث الثالث: نماذج لتربية الأبناء في الإسلام.

المبحث الرابع: العوامل الذي أدى إلى الانحراف وطريق معالجتها.

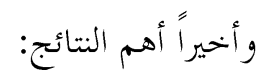

وضح القر آن الكريم والسنة النبوية أصول المنهج التربوي وحدد أساسياته وطرق أتباعه.

بناءاً على النتائج أوصي المربين بكل الطبقات ابتدءاً من الو الدين بان يقتدوا بالمنهج الإسلامي في تربية أبناءهم مراعاة لحق الله تعالى عليهم في تربيتهم.

المبحث الأول 


$$
\begin{aligned}
& \text { التربية في اللغة والاصطلاح } \\
& \text { والأبناء في اللغة والاصطلاح } \\
& \text { والإسلام في اللغة والاصطلاح } \\
& \text { أولاً: التربية لغة: }
\end{aligned}
$$

التربية لغة: من رب، والرب يطلق على الله تبارك وتعالى معرفاً بالألف واللام ومضافاً ويطلق على مالك الشيء، فيقال رب الدين ورب المال وقوله على السلام - ي ضالة الإبل حتى يلقاها

$$
\text { رها، وقد استعمل بمعنى السيد مضاف إلى العاقل (1) }
$$

وقوله (صلى الله عليه وسلم ): (حتى تلد الأمة ربتها ).

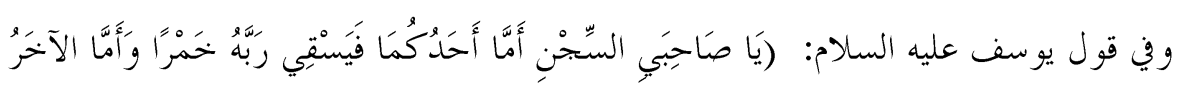

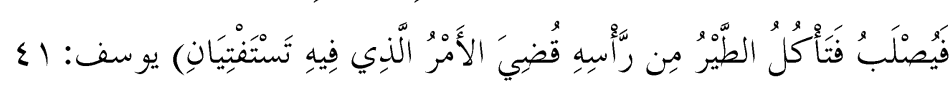

$$
\begin{aligned}
& \text { وقيل للحاضنة ربة وربيبة، والجمع ربائب، وجاء ربيبات على لفظ الواحد والابن ربيب والجمع } \\
& \text { أرباء مثل دليل و إدلاء. } \\
& \text { والرُبّّ الشاة التي وضعت حديثاً. } \\
& \text { ربا يربي إرباء فهو مربي والمفعول مربى به(2) } \\
& \text { فكلمة التربية أوردناها في معانٍ عدة بمعنى الرب والرب في القرآن الكريم والرب هنا هو الله عز }
\end{aligned}
$$

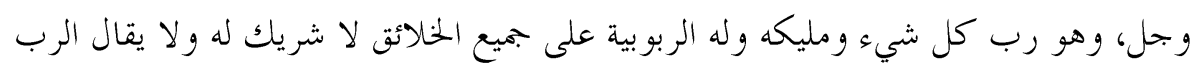

$$
\begin{aligned}
& \text { في غير الله إلا بالإضافة. }
\end{aligned}
$$




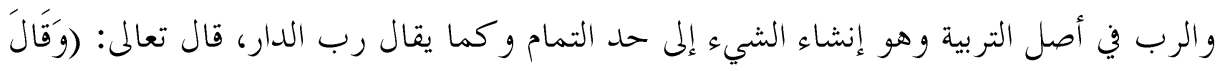

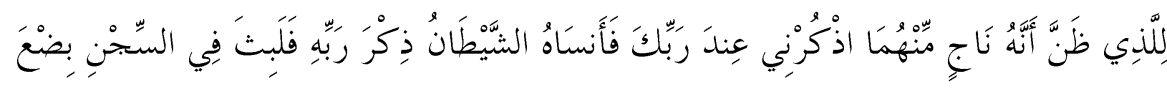

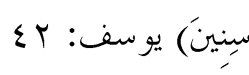

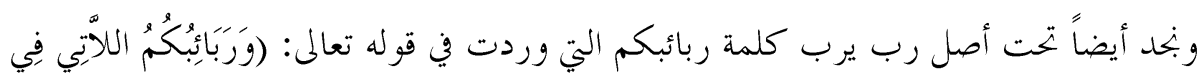

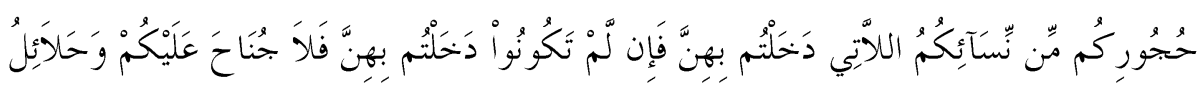

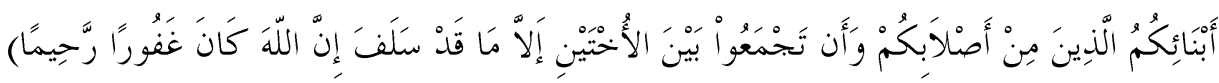

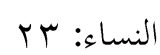

$$
\text { والربيب و الربيبة: .كعنى الوليد ؛ وربيب الرجل ابن امرأته من غيره (3). }
$$

وربب: من أشراط الساعة (أن تلد الأمة ربتها )، الرب يطلق في اللغة على المالك والسيد والمدير

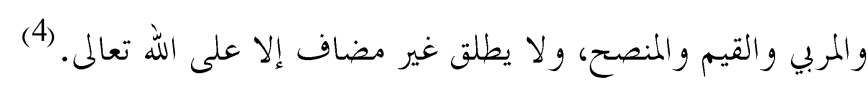
التربية أصلها من ربا الشيء يزيد و بابه عدا، الرابية ما ارتفع من الأرض، والربو: النفس العالي. ورباه تربية، ترباه أي غذاه وهذا لكل ما ينمي كالولد والزرع ونهوه وزنجيل

$$
\text { (مربي) ومرب؛ أي معمول بالرب.(5) }
$$

التربية في اللغة من ربَّّوهي كلمة تستعمل في الكلام لتقليل الشيء، تقول رب رجل جاءلي، وقال: الرباب العثور، وقال أبو ذؤيب: التوصل بالركاب حيناً وتؤلف الجور وتغشيها الأمان

كمثله ومتكأ كر جل ذهب يربأ أهله، أي يجفظهم من عدوّهم. 
إذن التربية في اللغة العربية لها معانٍ عديدة فمعنى التركيب و التعليم و التطهير كما قال تعالى:

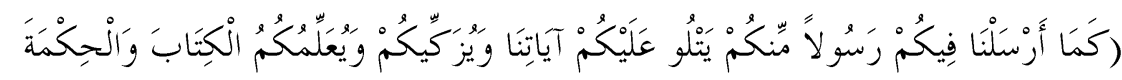

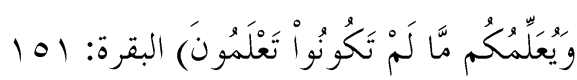

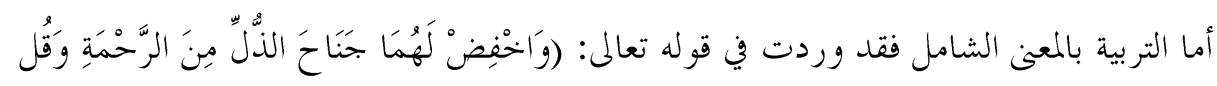

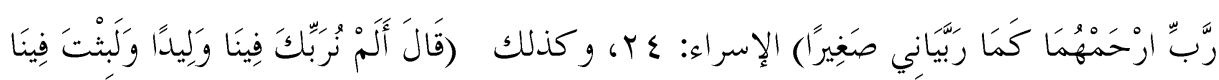

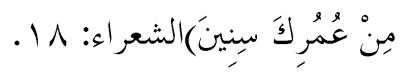

التربية اصطلاحا:

التربية في اصطلاح السلف تبليغ الشيء إلى كماله شيئاً فشيئا، أما في اصطلاح المعاصرين فالتربية هي تنشئة إنسان مسلم متكامل في جميع نواحيه المختلفة من الناحية الصحية والعقلية والعقائدية و الرو حية والأخلاقية والإبداعية وفي جميع مراحل نموه في ضوء المبادئ والقيم التي أتى هـا الإسلام

$$
\text { وفي ضوء أساليب وطرق التربية الصحيحة ورته }
$$

- واتفق علماء المسلمين على أن التربية عملية تحقيق النمو المتزن المنسجم لجميع استعدادات

$$
\text { الفرد النفسية والعقلية والخلقية حتى يصل إلى كماله. (7) }
$$

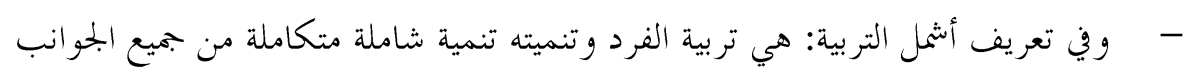

(الجانب الروحي والعقلي والنفسي والبدني والاجتماعي) ويجب ألا يطغي على آخر فهي تنمية

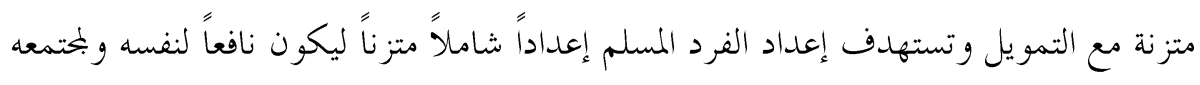

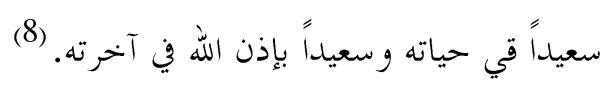
الأبناء لغة:

الابن وأصله بنو، فالذاهب منه كالذاهب من أب أو أخ ويقال ابن بين (النبوة) و تصغير بُنَيْ

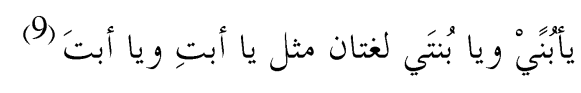

- - موابن الرجل وابنه ابناً وقال اللحياني: ابنته بغير ابن وابنة ابناً وهو مأبون بخير أو بشر. 
- وابن أي هالة في صفة بحلس النبي (صلى الله عليه وسلم)ومأبون مأذون من الابن وهي

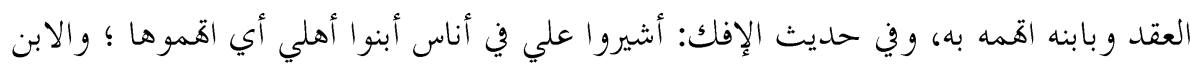
التميمة وفي حديث أبي سعيد (ما كنا تأبنه برقية )، أي ماكنا نعلم أنه يرق فتعجبه بذلك.(10)

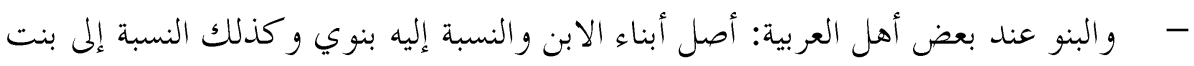
وإلى بنيات الطريق. - وكما وردت كلمة الأبناء في القرآن الكريم في عدد كبير من الآيات. الأبناء اصطلاحاً:

البنوة هو من الابن وهو حيوان يتولد من نطفة شخص آخر من نوعه. (12)

وقيل البنوة: الابن: الولد سمي ابنا للأب لأنه الذي بناه وجعل إليه سبباً لإيجاده، ويقال كل ما يكصل من جهته شيء أو تربية أو تفقده أو كثرة خحدته أو قيامه بأمره.

ابن نخو ابن السبيل للمسافر، وابن الحرب للمجاهد، وفلان ابن بطنه وابن يومه إذا لم يفكر في

- - - قيل الابن أصله (بني) بالياء، ما قيل إن معناه أنه يبني على ما بنى أبوه.

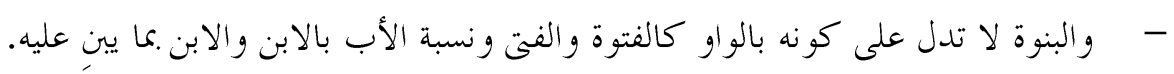

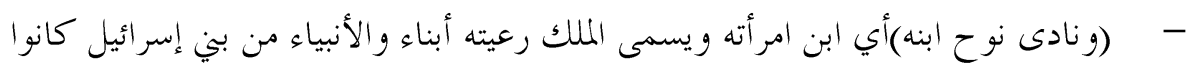

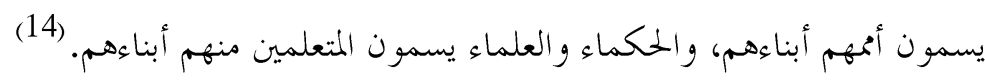

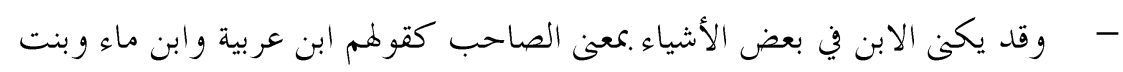

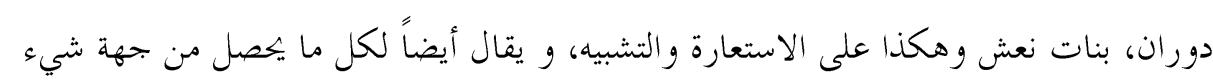

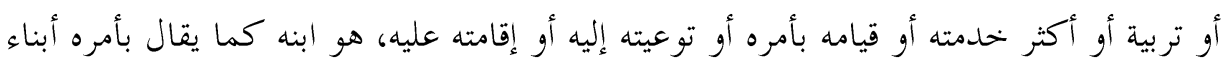
العلم، وأبناء السبيل وأبناء الدنيا. 
فالمعنى الحقيقي لابن: هو الصبي وكذا للولد منفرداً وجمعاً ولكن العرف اسم الولد حقيقة في ولد الصلب واستعمال الابن والولد في الابن والابن بحاز ولهذا صح أن يقال (إنه ليس ولدي بل ولد

فلابد من قرينة صارفة عن إرادة المعنى الحقيقي إذا استعمل في ابن الابن أو في معنى شامل كما في قوله تعالى: \}يا بني آدمج\{ فورود الخطاب قرينه صارفة عن المعنى الحقيقي، فيكون المراد أبناء الأبناء فقط لا معنى شاملاً للابن الأصلي وابن الابن، وهذا لا يدل على صحة استعمال لفظ رولى

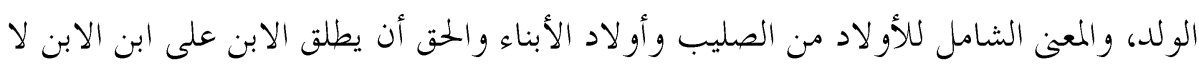
يستلزم إطلاق الولد على ابن الابن، فإن حكم لفظ الابن مغاير لحكم لفظ الولد في أكثر المواضع. (n) فيتناول لفظ الابن ابن الابن وإنما يدل على تناول الولد لابن الابن أن لو كان لفظ الولد مرادفاً

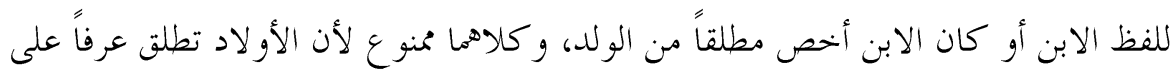
أو لاد الأبناء، بخلاف الأبناء و كذا.

تطلق عرفاً بدخول الحفيدة، فبينهما عموم وخصوص وجهي فلا يلزم من تناول في معنى واحد قال تعالى: \} يذبحون أبناءكم \{ وهنا المراد الذكور خاصة. (15) الإسلام لغة: الإسلام من سلم وهي الاستسلام، والسلم بفتح اللام واحدة السلاليم التي يرتقي عليها و السلم السلام.

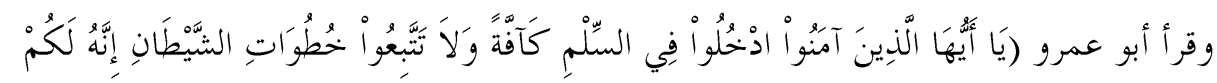

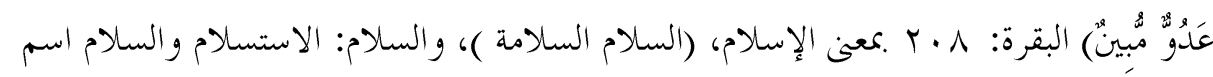
من التسليم، السلام اسم من أسماء الله تعالى، و السلام البراءة من العيوب في قوله تعالى: (ضَرَبَّ

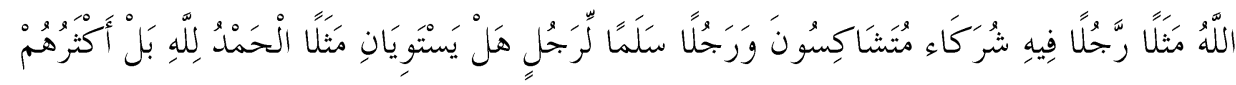

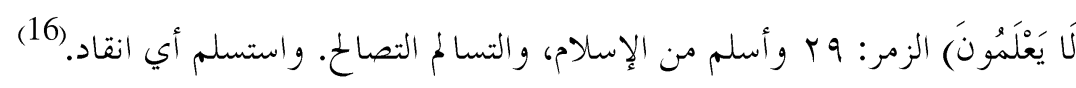


والإسلامي سلم وأسلم الله فهو مسلم وأسلم دخل في دين الإسلام، وأسلم في السلم وأسلم أمره الله وسلم أمره لله،وواستسلم انقاد. وقيل الإسلام من السلامة والسلامة والسلم بكسر فسكون من الصلح و و استسلم: انقاد وسلم الأجير نفسه للمستأجر: مكنه من نفسه حيث لا مانع والسلم بضم السين وكسرة اللامّ مشددة: ما يتوصل به إلى الأمكنة العالية فترجى به السلامة(18) الإسلام من أسلم يسلم إسلاماً فهو مسلم، والمفعول مسلم للمتعدي وأسلم الشخص دخل في

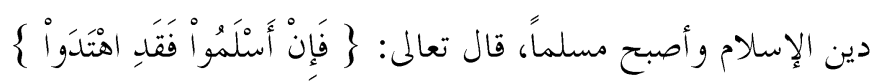
وأخلص الدين الله وانقاد وخضع له، قال تعالى: $\}$

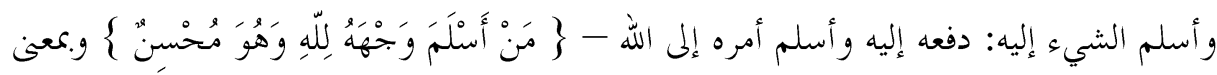

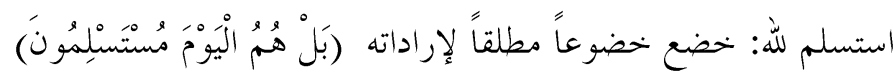
الإسلام اصطلاحاً: إذ أن الإسلام هو الخضوع و الانقياد وسمي المسلم مسلماً لخضوعه وانقياده لما جاء به سيدنا محمد (صلى الله عليه وسلم)له معنيان عام وخحاص، فالعام: يطلق على جميع الأديان السماوية التي اشتملت على ما جاء من عند الله عز وجل. والخاص يطلق على ما جاء به محمد (صلى الله عليه وسلم)، إذن التعريف العام للإسلام: هو الدين الذي جاء به محمد (صلى الله عليه وسلم) والذي يشتمل على العقيدة والشريعة والأخلاق (20)

والإسلام بالمعنى الخاص هو ما عرف به الرسول (صلى الله عليه وسلم) في حديث عمر رضي الله عنه لما سأله جبريل عليه السلام عن الإسلام .مقابل الإيمان والإحسان، قال: الإسلام: أن تشهد أن لا إله إلا الله وأن محمداً رسول الله وتقيم الصلاة وتؤتي الز كاة وتصوم رمضان وتحج البيت أن استطعت إليه سبيلا)(21) 
فالإسلام بمعناه العام يشتمل على جوانب العقيدة التي تتمثل في أركان الإيمان، فهي الإيمان بالله

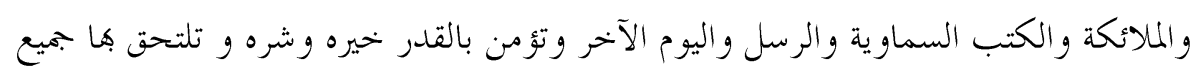
المسائل العقيدية التي جاء بها الإسلام.

والإسلام يشتمل على جانب الشريعة أيضاً التي جاء ها الإسلام سواء كان نظام المعاملة (الدين المعاملة)و الاقتصاد والأحوال الشخصية و السياسية والاجتماع و الحسبة والجهاد... الخ.

و كما يتمثل الإسلام في جانب الأخلاق وهي الصفات الكريمة والسلوك المستقيم الذي جاء به الإسلام قال رسول الله (صلى الله عليه وسلم ): (إنما بعثت لأتمم مكارم الأخلاق).(22)

من الإحسان كما جاء في حديث جبريل لما سئل عن (الإحسان قال: أن تعبد الله كأنك تراه، فإن لم تكن تراه فإنه يراك ). وهذا الجانب يعرف بنظام السلوك أو نظام الأخلاق في الإسلام. 
المبحث الثالي

\section{القواعد الإسلامية للتربية}

لإعداد جيل واعد يحمل في قلو به وعقوله على تمثيل مبادئ منهج وسلوكك في حياهم ليكونوا دعاة بأقو الهم وأعمالهم وأخحلاقهم وسلو كهم، و إذا لم بعد جيل واعد قد تعرض بحتمع الإسلامي للتفكك والانحلال وفقد الأهداف، كما تعرضت له الدعوات السابقة، و كان الرسول (صلى لى له

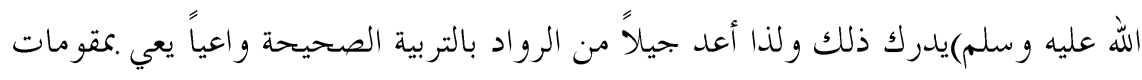
الرسالة وأهدافها ويحملها مطلقاً إلى الآفاق عبر تتابع الزمان والمكان (فالرسالة عالمية لتعمير الحياة وتعيش الأمة في محبة وتفاهم وتعاون في ظلال الحق والعدل والخير والحرية )

من أهم المبادئ التي حرص عليها الإسلام في جميع البحالات التدرج في بحالات التربية خاصة، وجاءت السنة القولية والعملية والتدرج في التعليم وكما في تقصير الصلاة من ركعتين في السفر إلى خمسة في الحضر، و كما حرم الخمر والربا وغيرها فمنهج التدرج الحكيم يسهل على المتلقين امتثال الأمر واجتناب النواهي في غير حرج. (24) فمفهوم المنهج التربوي هو مبادئ وخصائص التربية الإسلامية الصحيحة. هو ما جاء به القرآن الكريم يوجه الآباء ويأمرهم بحماية أبنائهم من الفسوق والضلال والجور،

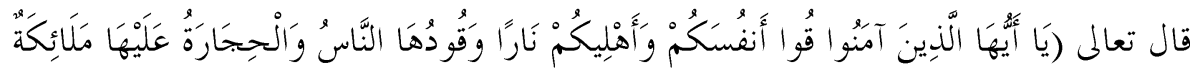

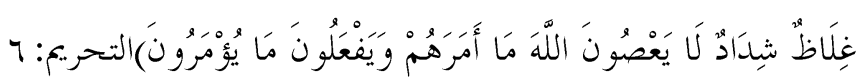

فالقرآن الكريم بتوجيهاته السامية جاء ليربي الفرد المسلم في جميع مراحل حياته ؛ فهو يريد

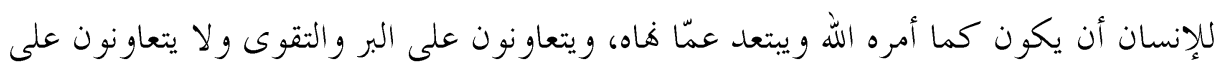
الإثم و العدوان ويدعو إلى الله ببصيرة وحكمة والموعظة الحسنة. 
فالقر آن جاء منهج متكامل للفرد والأسرة والمختمع فلم يقتصر على العبادة دون السلوك و لم يختص بالفرد ويترك المختمع، فهو منهج ملحوظ في نواميس الفطرة التي تعرف بالنفس البشرية في أطوارها وأحو الها، فهو يعالج النفس المنفرد و الجماعة وعلى هذا الأساس يمكن أن نختصر التربية إلى قو اعد التربية الإيمانية والتربية الخلقية والتربية الجسمية والعقلية والتربية الاجتماعية.

$$
\text { أولاً: التربية الإيمانية: }
$$

هو إيمان وعمل موثوق متقن بقناعة روحية وجسدية، فالإيمان ما تمثله أركان الإيمان من إيمان بالله والملائكة والكتب والرسل واليو الآخر و القضاء خيره وشره، وهذه أساسيات الإيمان والإسلام والأغلبية منها غيبيات مفطورة مع الإنسان، فالوحي الإلهي هو الذي وضع أصول خصائص المنهج التربوي الإسلامي وحدد الأساسيات التي لابد منها لبيان معالم الشخصية الإسلامية (25)

أما التربية الإسلامية فنعني ها تطبيق ما جاء في أر كان الإيمان على الوجه الصحيح ؛ فالإسلام أن

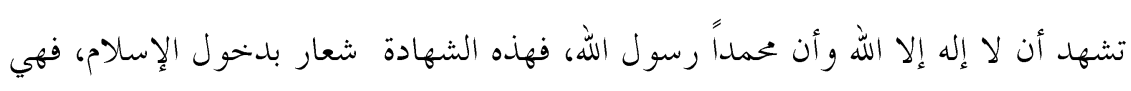

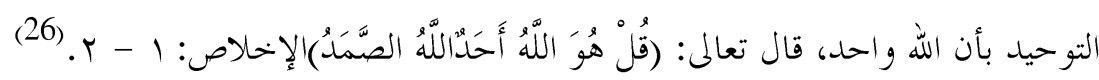

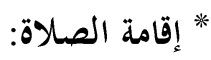

ونعلهم أولاً كيفية الصلاة مشتملة شروطها التي بينها رسول الله (صلى الله عليه وسلم ): (صلوا

$$
\text { كما رأيتمو ني أصلي)(27) }
$$

$$
\text { * إيتاء الز كاة: }
$$

و الز كاة هي الصدقة الو اجبة على كل مسلم مستطيع لأها تطهير النفوس من الشح والبخل والحقد والحسد وتطهر المال وتقي الخحتمع من الجرائم والسرقة وخلافه، قال تعالى: (خُخْ مِنْ 


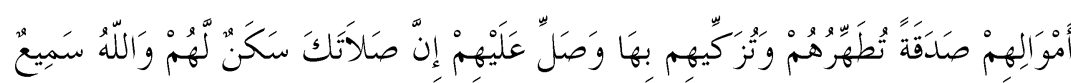

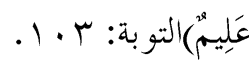

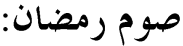

و تعليم درجات الصوم وأن الله قد فرض لهم وقت الصوم وشهر الصوم. وما يحل للصائم وما

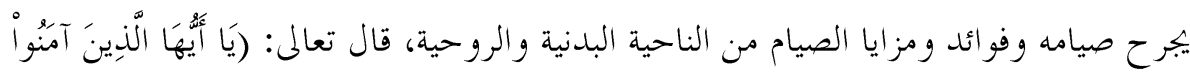

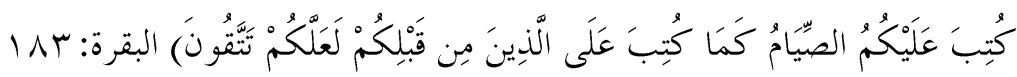

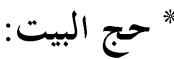

كما يجب علينا إن نعلم أبناءنا أن الله قد فرض الحج على كل إنسان أن يهج البيت مرة في العام

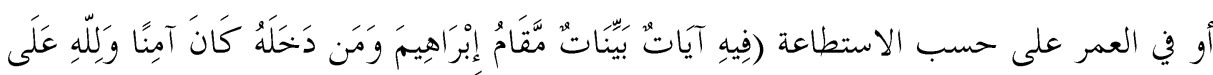

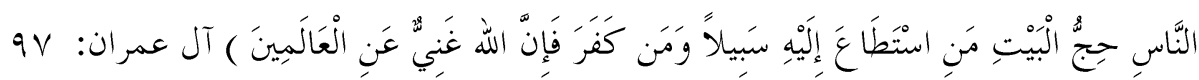

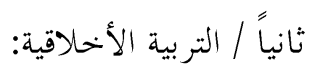

التربية الأخلاقية على أساس العقيدة وبيان أثر العقيدة في سلوك الإنسان، والحياة الأخلاقية لا

يمكن أن تنمو (دون الاعتقاد في الله، فقد حرص الإسلام على تربية أبنائنا عقائدياً بغرس في نفوسهم منذ اللحظة الأولى عندما يولد الطفل يتلقى كلمة التوحيد بآذان في أذنه وهي شعار تنبيه الفطرة على الظهور كما قال رسول الله صلى الله عليه وسلم: (كل إنسان يولد على الفطرة فأبو اه يهودانه أو ينصرانه أو يمجسانه) (29)، فالدين والأخلاق شيء لا يقبلان الانفصال، فالدين هو الروح للأخلاق ومسؤولية شاملة لتصلح نفوس الأطفال ونقوي اعوجاجها. كما أن حسن معاملتهم للآخرين يقي تخفيف الأداء منذ الصغر على الاستقامة وحب الخير وتربيتهم على الصدق والأمانة وإغاثة الملهوف واحترام الكبير وإكرام الضعيف وإكرام الضيف 
والإحسان إلى الآخر ين وحفظ ألسنتهم من الشتائم وفساد الخلقى، وتربيتهم على الشرف والفقه

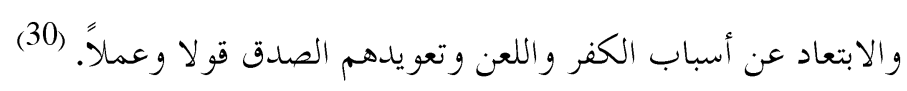

ونعود أبناءنا أن يفعل الذكور مثل أفعال الرجال، والبنات مثل أفعال النساءو و لا نشبه الصبية

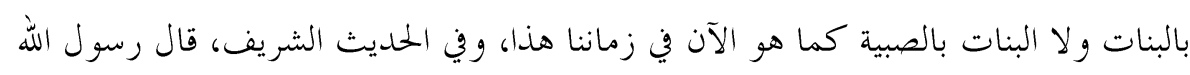

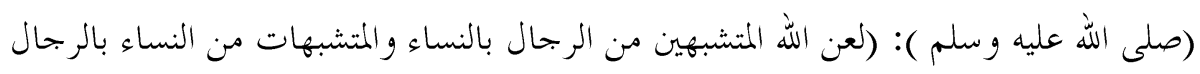
(31).

وأن تكون هناك حشمة في اللبس سواء كانت امرأة أو رجلاً بشرط أن يكون لباساً دينياً ساتر

$$
\text { يميّز الرجل عن المرأة. }
$$

\section{ثالثاً / التربية الجسلدية والعقلية: - م}

التربية الجسادية والعقلية هي السبيل لتكوين الإنسان الصالح، وهي مظاهر الصحة والحيوية

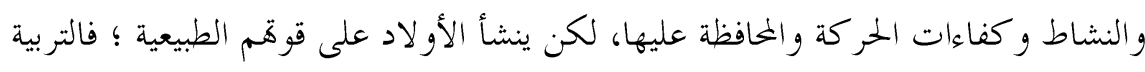

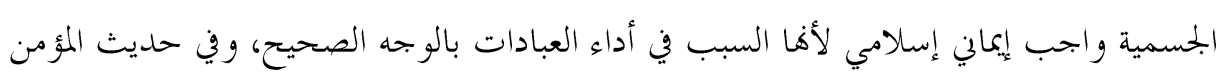

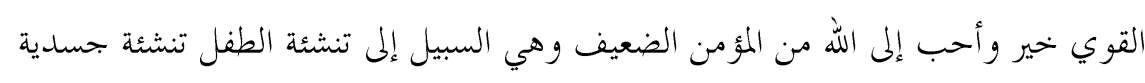
سليمة. ومن الأسباب الفطرية للطفل السليم التباعد في الزواجه لأن الطفل يرث الصفات الفطرية وقد

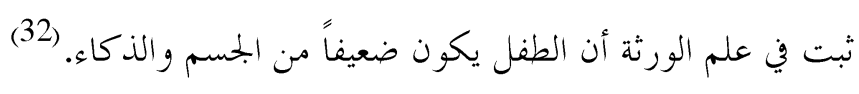

فالتربية لا تقف بل تستمر من الحمل إلى أن يولد الطفل وفي مراحل نموه الحياة، وقد اكتشف كالتف

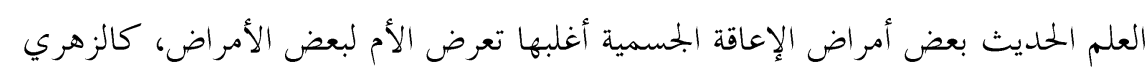

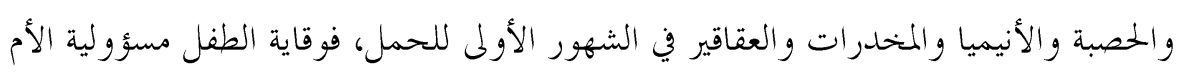

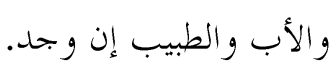


- وبعد الولادة واجب عليها العناية والاهتمام بالطفل بعناية تامة والاهتمام به، و إتمام

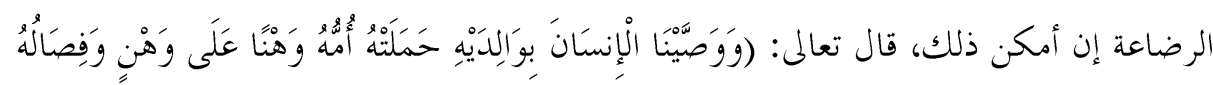

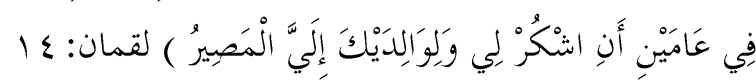

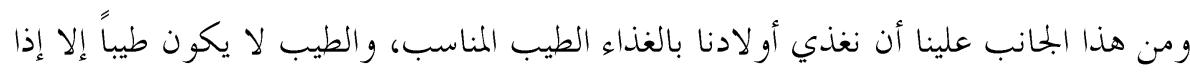

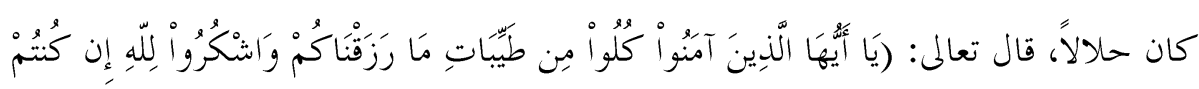

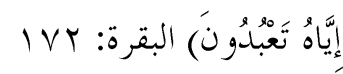
فكل نوع رديء وحرام من الطعام لا يستفيد منه الجسم و كما، يجب على الو الدين وقاية أطفالمم من المرض، قال رسول الله (صلى الله عليه وسلم ): (ما انزل الله من داء إلا انزل له دواء)(33) وأسباب التربية الصحيحة الوقاية من الأمراض بالنظافة البدنية والبيئية قال تعالى: (وَلاَ تُلْقُوْ

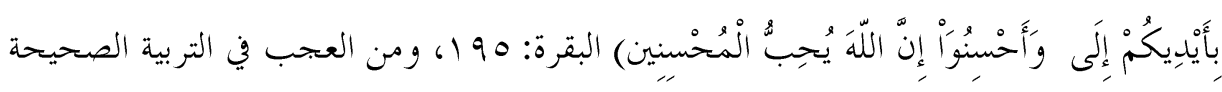
و الشفاء السريع للطفل وإدخال ما يسره من أقوال وأفعال والرقية الشرعية والتعوذ من الشيطان،

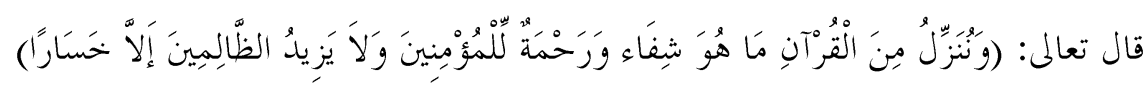

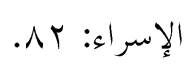

و التربية الجسمية والعقلية واجب اجتماعي، تغرس الخبة والنظام والتعاون والإيثار عن أبي علي

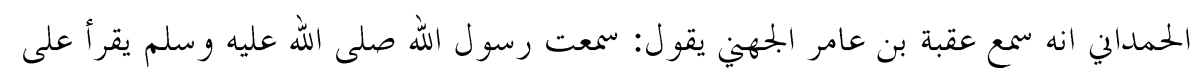

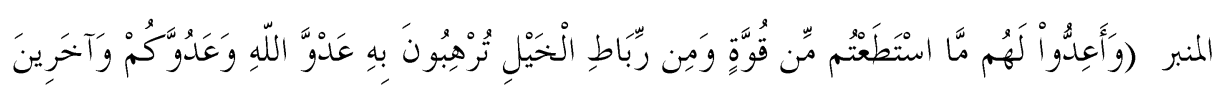

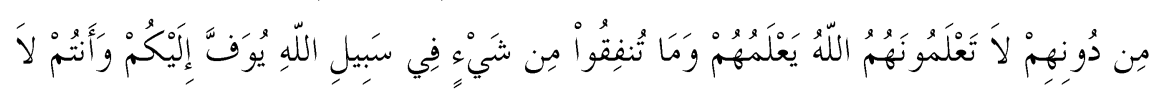

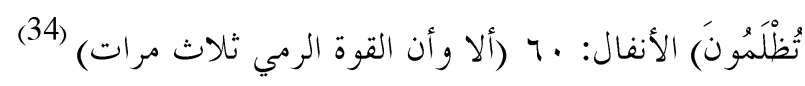
وعدم الرياضة يقلل من حدة الذكاء وكما يجب التحذير من الظواهر السيئة مثل التدخين و والمسكرات و الزنا وخحلافه. 
- - كما أن للعقل البشري طاقة من أكبر الطاقات على الإطلاق وهبه الله تعالى للإنسان

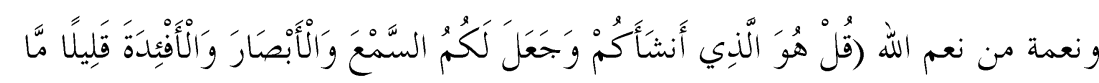

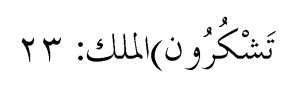

فالعقل ينمو مع تكييف البيئة الموجود فيها ويزداد تدريجياً نخو الأعلى على حسب تغذية المسلم ويمكن السيطرة عليها في الاتحاهات، ويبدأ الإسلام بتحديد بجال النظر العقلي وتصوير الطاقة العقلية وتبدد من وراء الفساد وهي التأمل في حكمة الله تعالى وتدبيره على إقامة الحياة على لئل أساس الحق والعدل، فتوجه العقل لضمان سير الأمور في المجتمع على منهج صحيح ويوجه القرآن الطاقة العقلية إلى النظر في سنة الله في الأرض وأحوال الأمم والشعوب على مدار (التاريخ. (1)

وهنا توجه العقل إلى استخلاص الطاقة المادية لتذللها لخدمة الإنسان، وهذا هو الإسلام يحرص أشد الحرص على ربط القلب دائماً بالله تعالى ويوجه العقل إلى حكمة الله في خلقه، فالعلاقة

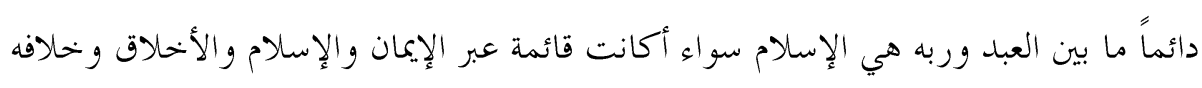

هي علاقة مودة وحب وتطلع ورجاء. (35)

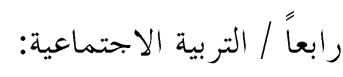

وكما يجب علينا أن نربي أولادنا كيف يتعاملون مع الناس بكل الأصناف و التواضع معهم، فعليهم احترام الكبير وتوقير الصغير وحسن التحدث مع الآخرين، قال الله تعالى على لسان

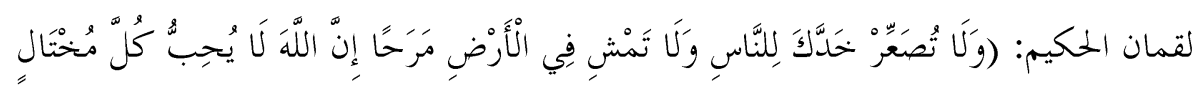

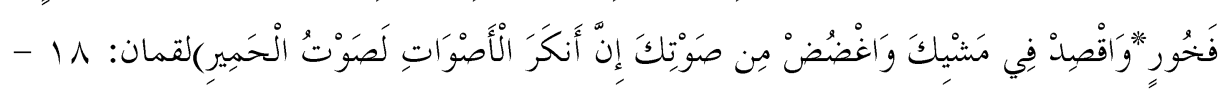

1

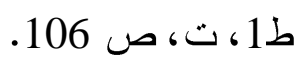


و التربية على حسن الخلق قال: رسول الله صلى الله عليه وسلم: (من حسن إسلام المرء تركه ما لا يعنيه). (36)

$$
\text { موطأ مالك، كتاب حسن الخلق، باب ما جاء في حسن الخلق، حديث رقم3. }
$$

وفي حديث آخر لرسول الله صلى الله عليه وسلم (أن المرء ليدرك بحسن خلقه درجة القائم بالليل الظامي بالهو (جر) موطأ مالك، مرجع سبق ذكره، رقم الحديث6). (ألا أخبر كم بخيار كم ؟ قالو ا: بلى، قال أحسنكم أخحلاقًا وأن أحبكم إلى أقربكم مين بحلساً يوم

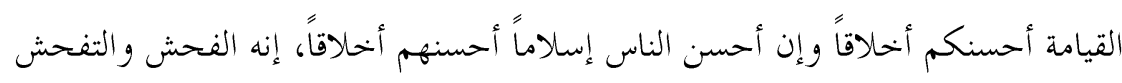
والتفحش ليس من الإسلام وأن حسن الخلق يذيب الخطيئة كما تذيب الشمس الثلج، وأن الناس

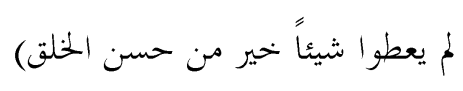

فالتربية الاجتماعية دخل فيها حق الجحار، قال الرسول (صلى الله عليه وسلم): (ما زال جبريل

$$
\text { يوصيني بالجار حتى ظنت أنه سيورثنه)(38) }
$$

و كما نربي أولادنا على عيادة المريض ففيها حسنات وتخفيف الألم وحق الجار وعيادة المريض

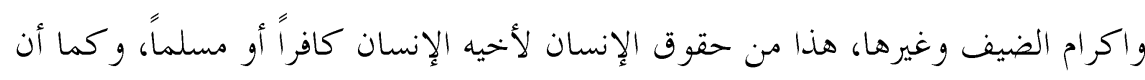
للتربية آداباً وحقوقاً وواجبات.

ومن الأعمال الاجتماعية بر الو الدين لأن الو الدين من ضمن البختمع من حول الأبناء، فالبر هو: لفظ جامع للخيرات كلها وير اد به التخلق بالأخلاق الحسنة مع الناس من حولك وبالإحسان

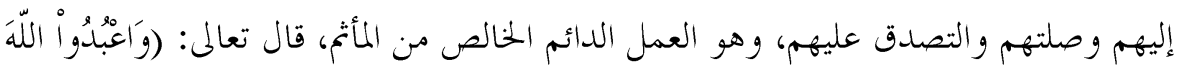

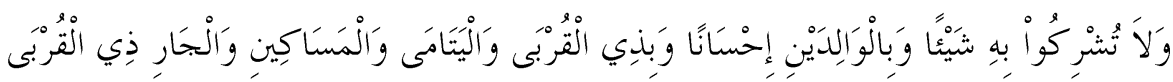

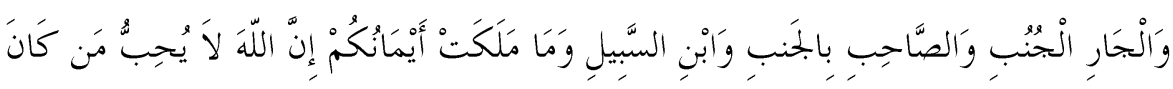

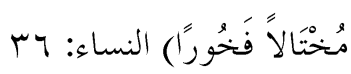


و كما قام الوالدان برعاية وتربية أبنائهم فبلغ من تقديره وعناية فلهم الحق العظيم في برهم

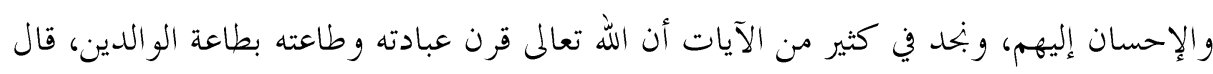

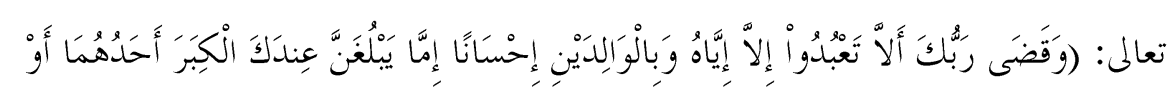

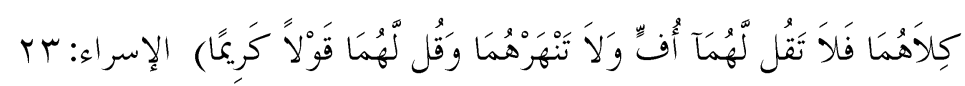

\section{المبحث الثالث}

\section{نماذج لتربية الأبناء في الإسلام}

من الأصول التي قامت عليها تربية الإنسان في الإسلام الفطرة السليمة التي تؤمن بالله رباً وخالقاً،

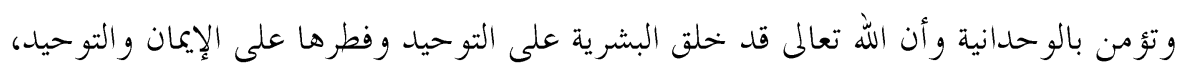

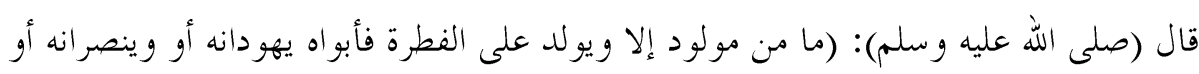

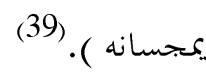

ووصية لقمان لابنه ركزت على الملامح العامة لتربية الطفل وتمثل في تربيته على الأمر بالمعروف

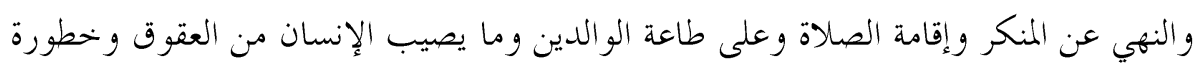
الشرك، فالأساليب التربوية لهذا الرجل الفانل الحكيم عديدة.

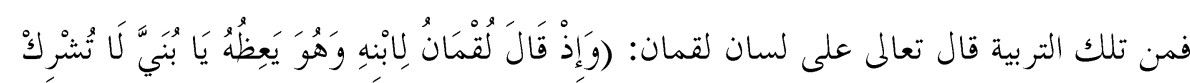

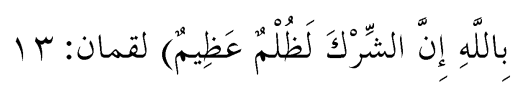

فالعقيدة هي أساس التربية الإسلامية والإيمان بالله هو الموجه لسلوك الإنسان والدافع إلى اتجاه

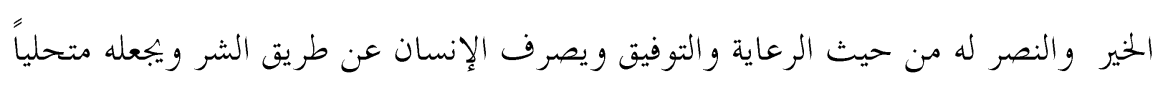

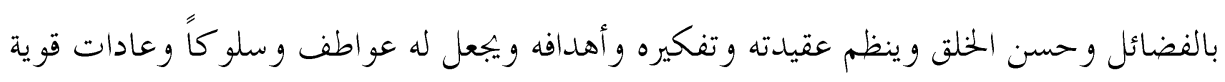

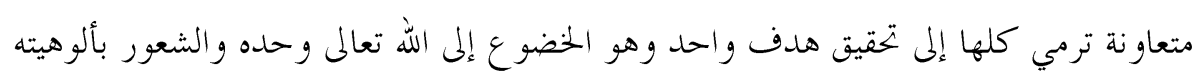
وحاكميته ورحته في النفوس. (40) 
وقد بدأ لقمان الحكيم دعوته لابنه وللأبناء جميعاً بعدم الشرك بالله وأن الله واحد يستحق العبودية والشرك بالله هو أساس الظلم ويتفرع منه بقية المظالم. و الشرك باللة: هو كل عمل أو قول أو اعتقاد أمر الله به أمر إيجاب أو استحباب فصرفه لغير الله، فالظلم أنواع ومستويات، فأي ظلم يوقع فيه الإنسان نفسه حيث ينحرف عن هذه الحقيقة الهائلة التي تقوم عليها السماوات والأرض، وأي ظلم في إنكار الحق الذي يستجير به الكون كله ويقر به وأي ظلم أن يورد الإنسان نفسه موارد الملاك في هذا الإنكار ! وحتى السموات والأرض

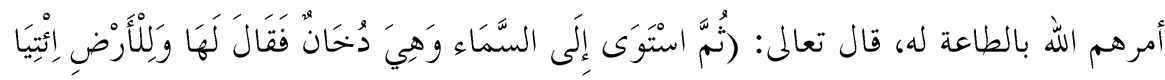

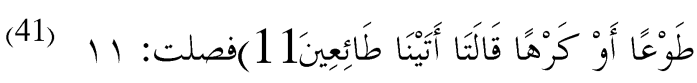

ومن هذه الحقيقة يصف القرآن الشرك بأنه ظلم كبير عظيم، ويصف المشر كين بأهم ظالمين، قال

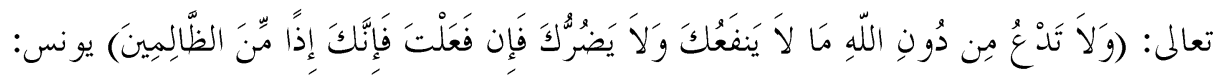

فالشرك انحراف عن المهمة التي خلق الجحن والإنس من أجها، قال تعالى: وَمَّا خَحَقْتُ الْجِنَّ

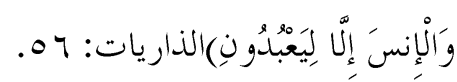

و الشرك يضفي نور الفطرة،فالإنسان بابتعاده عن حقيقة التوحيد التي يستمد منها إشراقه ونوره

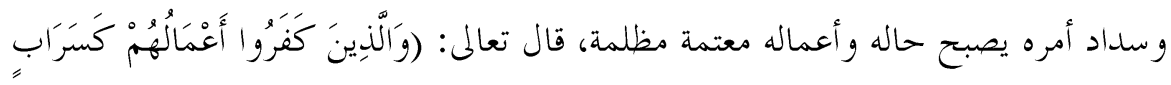

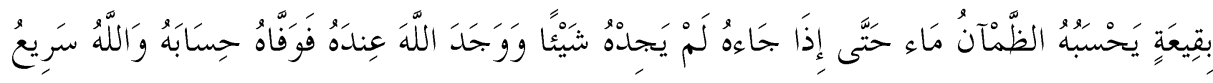

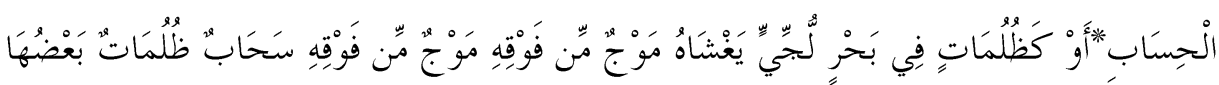

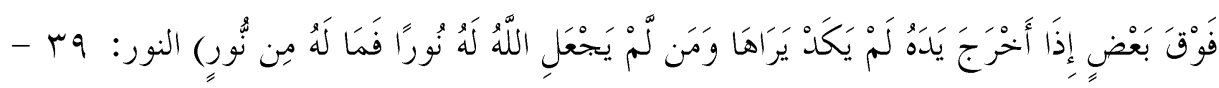
•ع، و الشرك بالله يقضي على منازع النفس السامية المتعلقة بالله تعالى، والمتطلعة إلى رضاه بمبدأ عن شهوات النفس ومتاع الدنيا. 


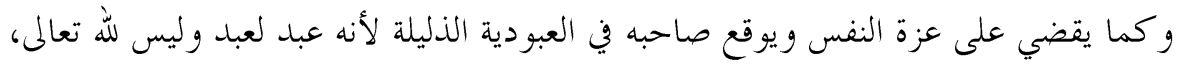

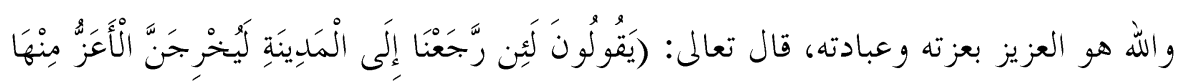

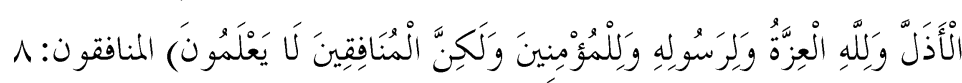

ونربي أبناءنا بأن الشرك بالله يمزق النفس البشرية والتوحيد حصيلة بتمع النفس البشرية باتحاه

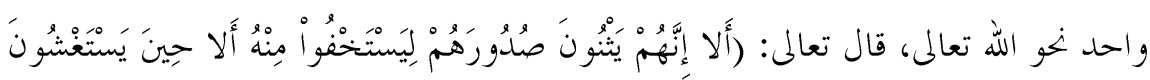

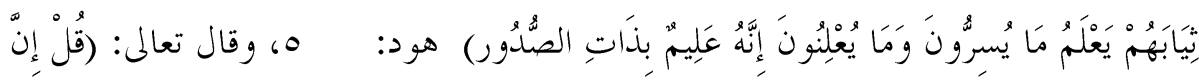

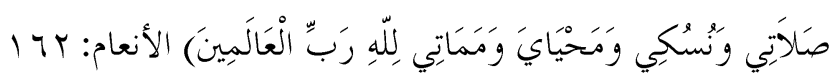
وبذذا نلخص الشرك في ثلالة أقسام رئيسية أساسية:الشرك الأكبر والشرك الأصغر والشرك الخفي. فالشرك الأكبر ينفي الإسلام كلياً. والشرك الأصغر هو ارتكاب كبائر الذنوب.

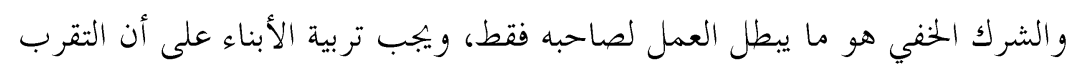

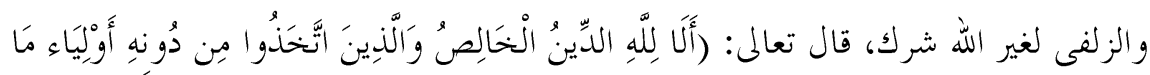

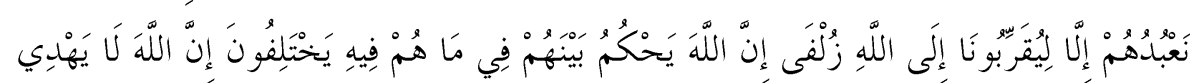

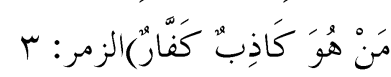

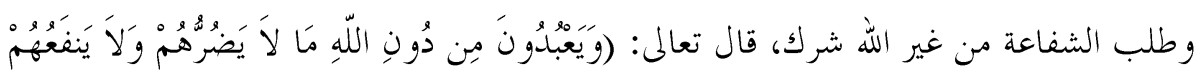

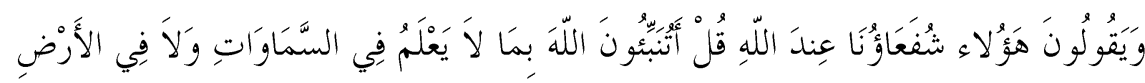

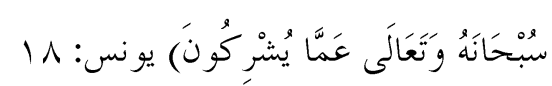

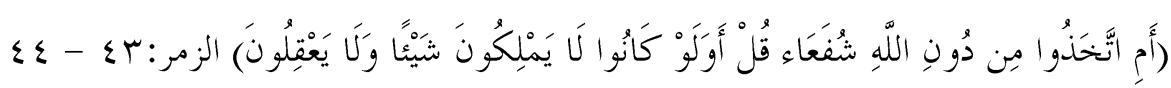

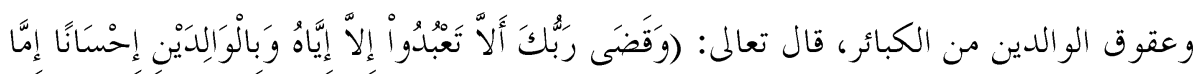

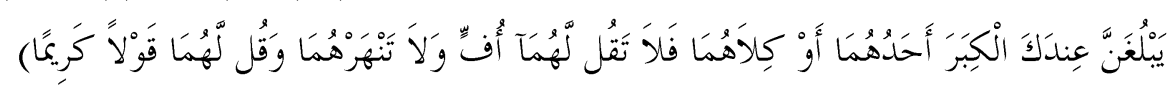
الإسراء: بr 
فبرهما الشفاعة وعطفهما واجب وصى به الله تعالى وبالذات عند الكبر، لا تقل لهم كلمة

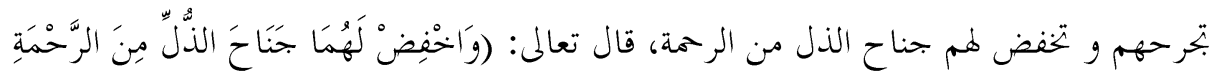

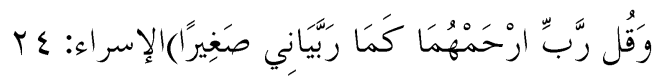

فعقوق الو الدين أخذ مظاهر عديدة وصوراً شتى فمن الأبناء من يحزن والديه سواء بالقول أو

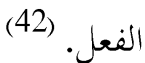

فرفع الصوت و العبوس وتقطيب الجبين في وجه الو الدين وعدم البشاشة وعدم انتقاء الكلام الطيب وعذب الحديث في حضرقما يجعلك عاقاً لمما.

تتعدد صور عقوق الو الدين كل على حسب حالته والانشغال بالمال و النفس والولد وملاهي الحياة وملذاها يؤدي إلى ابتعاد الأبناء عن أبائهم و بالتالي قد تقع في عقوق الو الدين بالابتعاد

ثانياً: ركز لقمان الحكيم في تربيته للأبناء على الأمر بالمعروف و النهي عن المنكر، قال تعالى: (يَا

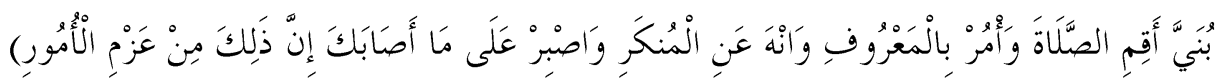
لقمان: Vا لمحا اختص الله به الأمة الإسلامية أن يجعلها شاهدة يوم القيامة على جميع الأمم من

قبلها لما تحمله من عبء الأمر بالمعروف والنهي عن المنكر وتلك مسؤولية مهمة من ميراث النبوة، لأن دعوة جميع الأنبياء في جوهرها أمر بالمعروف وهي عن المنكر.

ولا يتصور حال الأفراد والجماعات بلدون الأمر والنهي ولا يستقيم حال أمة من الأمم إذا لم يكن لديها ما تأمر به وما تنهى عنه.(43) وفي حديث رسول الله (صلى الله عليه وسلم): (من رأى منكم منكراً...) 
و التربية الأخلاقية في الإسلام تتخذ من وجوب ممارسة الأمر بالمعروف والنهي عن المنكر ركيزة تقوم عليها ولا تستغني عنها بأي حال و البمتمع عندما يمارس كل فرد فيه الأمر بالمعروف والنهي عن المنكر فإن الأخلاق الفاضلة والخير والبر يسود المختمع كله. (44)

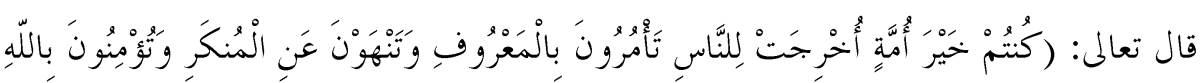

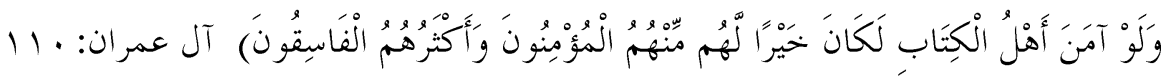

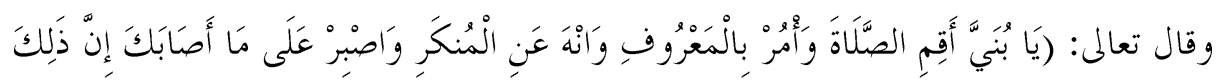

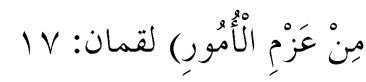
والأمر بالمعروف والنهي عن المنكر هو سفينة النجاة لأنه من أهم الواجبات الإسلامية.

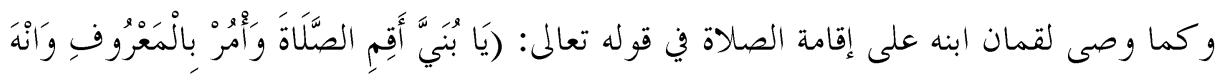

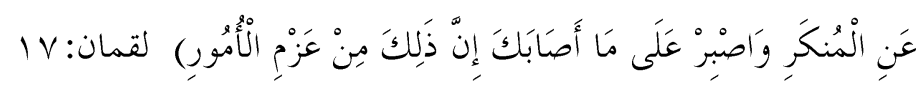

يعني الإسلام عناية خاصة بتربية الروح وهي نقطة الأساس لصلة الإنسان بربه وهي صلة دائمة في

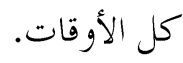

فالروح تبقى مشرقة لأها متصلة بخالقها، والصلاة هي أولى الفرائض ومنهج متكامل لتربية

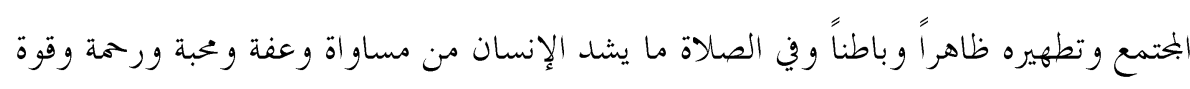
وأدب وواقع حي ملموس، هنا لا فضل لعربي على أعجمي إلا بالتقوى وفي إقامة الصلاة برهان

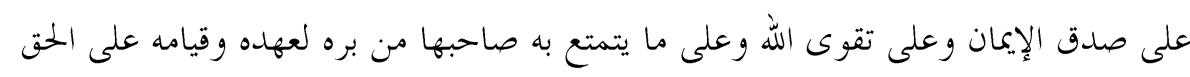
والتمسك بالكتاب وتحمل مسؤولية الإصلاح. (45) وأوصانا رسولنا الكريم أن نحافظ على الصلوات الخمس وهي فريضة على كل مسلم عاقل بالغ لا كافر ولا الجخنون، أما الصبي فعلى من يتولى تربيته أن يأمره بالصلاة حتى الضرب كما جاء عند بلوغ السبع سنين وأن نضرهم عليها في سن العاشرة إذا لم يصلِ، ويجب على ولي الأمر 


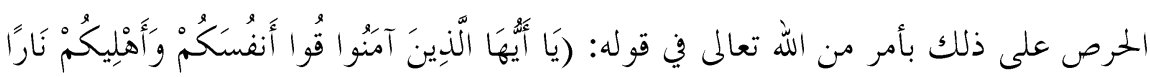

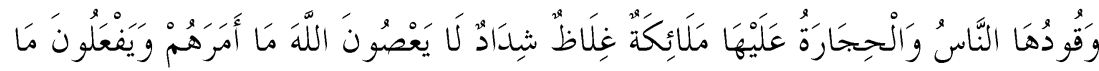

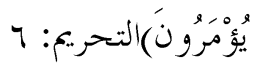

فنربيهم على عدم ترك الصلاة وأن تار كيها هم الضالون ومن فضل المواظبة عليها تدريب المسلم على النظام والنظافة واستقبال ربه بنفحات وخيرات فناره

وكما شرعت الصلاة في أول الإسلام لتكون زاد المؤمنين وقوة الموقنين ودواء المقدسين

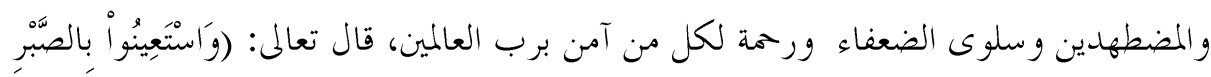

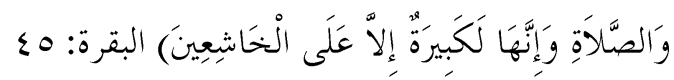

وشرعت الصلاة لتطهير القلوب من وسخ الجاهلية وقذرها وتطهير النفوس من أمر اضها،

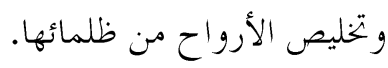

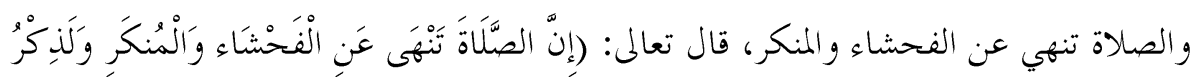

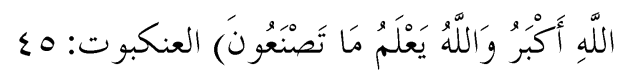

لقد لخصت أساليب التربية من خلال سورة لقمان في عدة أسايب أبرزها الموعظة في

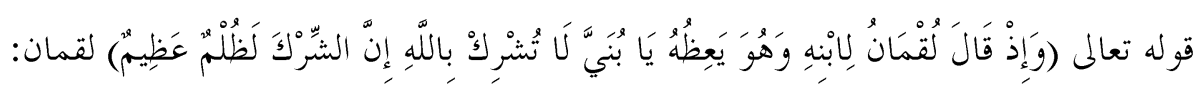

والمواعظ كثيرة في القرآن الكريم أما الملاحظة في هذه الآية و الآيات القرآنية الأخرى أها

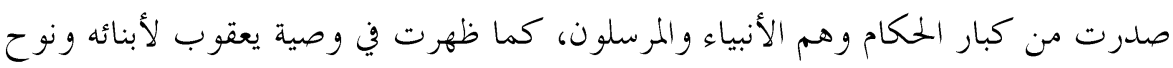

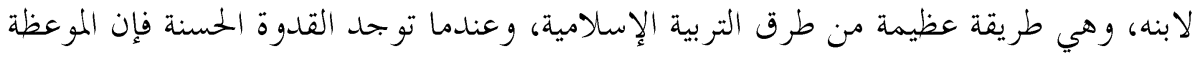

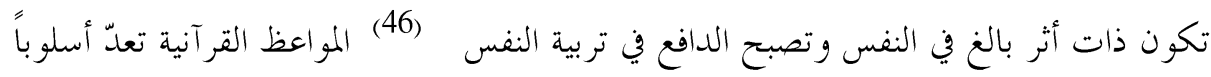

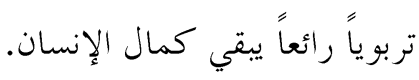
بند أن معظم المواعظ القر آنية تدور حول تربية الإنسان تربية عقائدية وسلو كية لتكوين وتنشئة وإعداد المسلم الصالح. (47) 


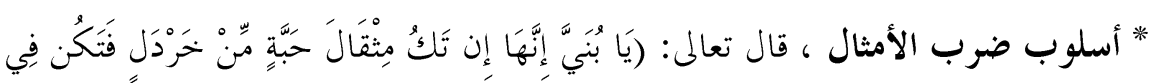

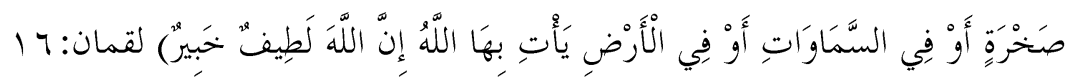

وتستخدم هذه الطريقة لتقريب غير الخسوس وتمثيل الأشياء غير المادية وغير المنظورة بحيث

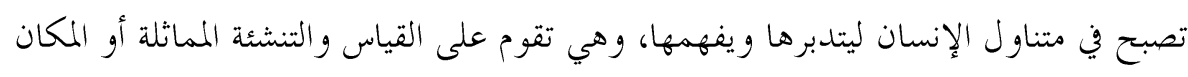

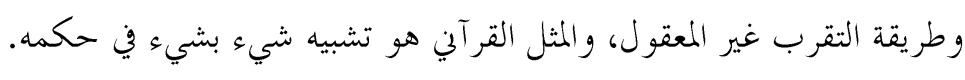

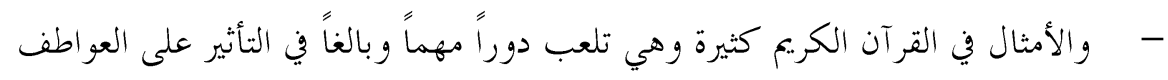

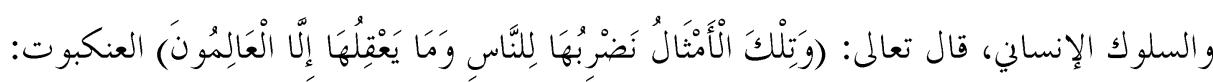
$\varepsilon r$ فالأمثال دائماً أوقع في النفس وأبلغ في الموعظة وأقوى في الزجر وأقوم في الإقناع، وقد أكثر الله

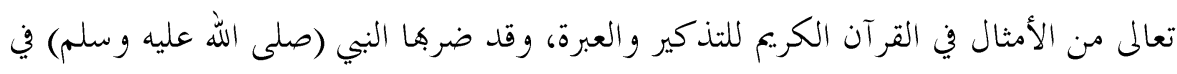

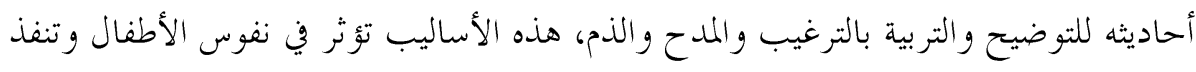
إلى الأعماق وتؤدي إلى الميل نخو الخير والحق. * الترغيب: هو أسلوب تربوي إسلامي تجري على فطرة الإنسان من الرغبة واللذة والنصح والرفاهية وحسن البقاء.48) ومن مميزات الترغيب يعتمد على الإقناع والبرهان.

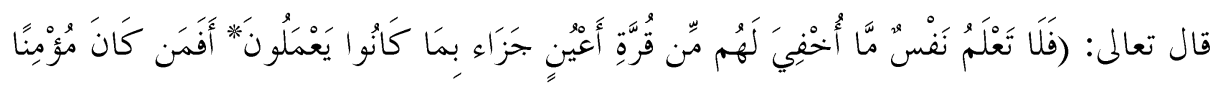

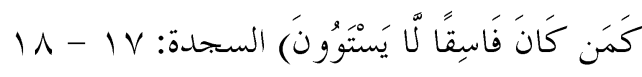

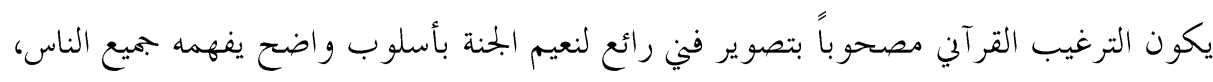

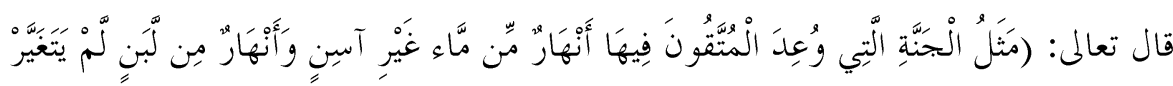

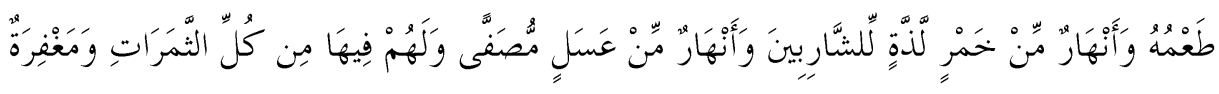

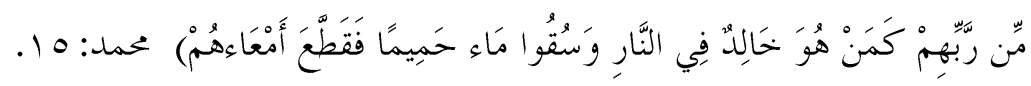


وكما يعتمد الترغيب القر آني على إثارة الانفعالات وتربية العواطف الربانية وهي مقصد

$$
\text { الشريعة ومن هذه تنتج انفعالات تتمثل في: }
$$

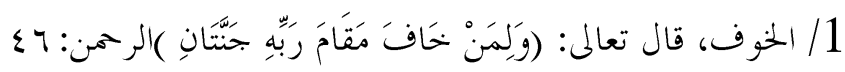

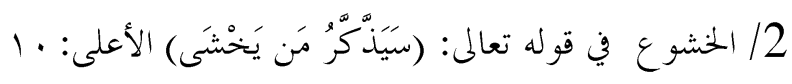

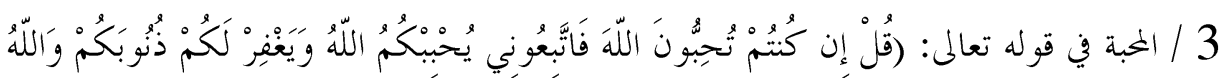

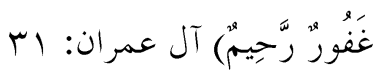

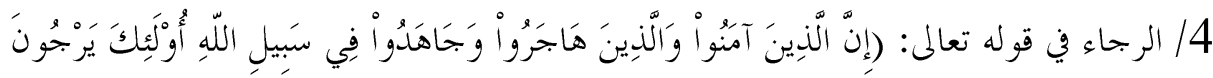

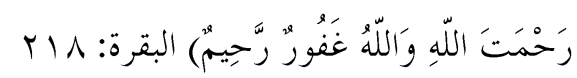

فالترغيب يعتمد على ضبط الانفعالات والعو اطف، فلا يجوز أن يطغي الخوف على الأمل

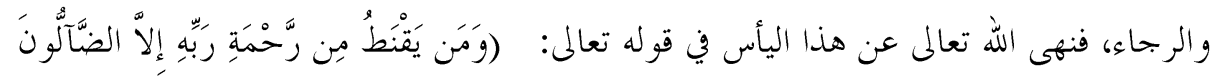
الخجر:

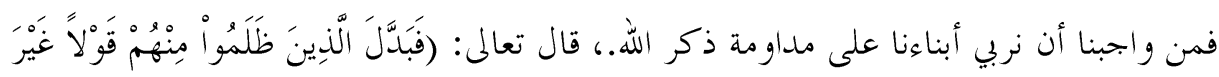

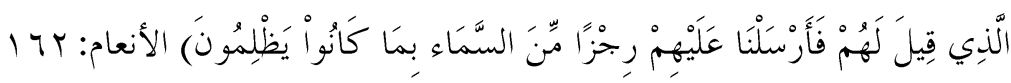

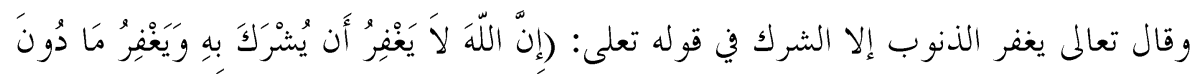

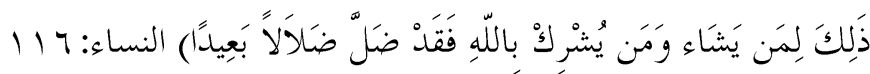

والقرآن الكريم كله دعوة إلى إصلاح الحياة الإنسانية بدأ بإصلاح المعتقدات والأفكار مروراً بالأنماط السلو كية، فجميع جوانب الحياة الاجتماعية الإسلامية يقرب بين الإيمان والإصلاح، قال

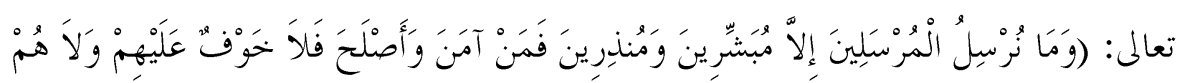

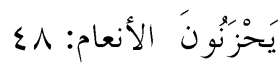


فالكتمع الذي يمارس أفر اده الإصلاح و المراجعة والتقويم والنقد الذاتي ويبادرون إلى إصلاح

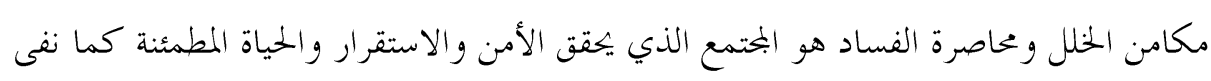
الله تعالى الخوف والحزن عمن آمن واتقى.

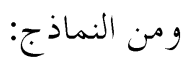

وصية نوح لولده من معاني الإسلام وترسيخه في العقول والاهتمام بالتوحيد والنهي عن

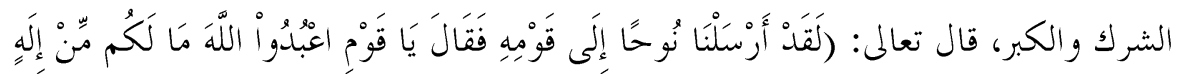

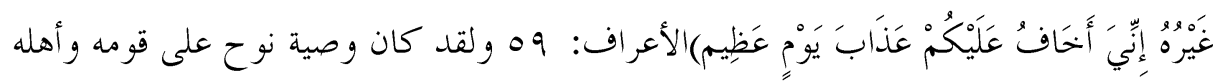
أجمعين وجاء في حديث الأمام أحمد: (حدثنا سليمان بن حرب، حدثنا حماد بن زيد عن الصقعب بن زهير، عن زيد بن أسلم: قال حماد: أظنه عن عطاء بن يسار: عن عبد الله بن عمرو قال: كنا عند رسول الله (صلى الله عليه وسلم) فيما رجل من أهل البادية عليه جبة سيحان، مزرورة بالديباج، فقال: (ألا إن صاحبكم هذا قد وضع لكل فارس ابن فارس)أو قال: (يريد أن يضع لكل فارس ابن فارس ويرفع عن ابن راع) قال: فأخذ رسول الله (صلى الله عليه وسلم)كحامع جبته وقال: (ألا أرى عليك لباس من لا يعقل ؟! ثم قال: (إن نبي الله نوحاً عليه السلام لما حضرته الوفاة قال لابنه: إني قاص عليك الوصية، أمرك باثنتين وأهاك عن اثنتين: أمرك بلا إله إلا الله، فإن السماوات السبع والأرضين السبع لو وضعت في كفة ووضعت لا إله إلا الله

في كفة رجحت لا إله إلا الله، ولو أن السماوات السبع والأرضين السبع كن حلقة مبهمة ضمتهن لا إله إلا الله وسبحان الله وبحمده، فإن بها صلاة كل شيء، وهما يرزق الخلق، وأهاك عن الشرك والكبر )، قال: قلت: يا رسول الله هذا الشرك قد عرفناه، فما الكبر ؟ أن يكون لنا نعلان حسنان لمما شراكان حسنان ؟ قال: (لا) قال: (هو أن يكون لأحدنا حلة يلبسها ؟ قال: (لا) قال: هو أن يكون لأحدنا دابة ير كبها ؟قال: (لا)، قال: هو أن يكون لأحدنا أصحاب يجلسون إليه ؟ قال: (لا)، قلت - أو قيل يا رسول الله، فما الكبر ؟ قال: (سفه الحق وغمط 
ومن النماذج القر آنية وصية إبراهيم ويعقوب عليهما السلام لأبنائهم عندما حضر هما الموت:

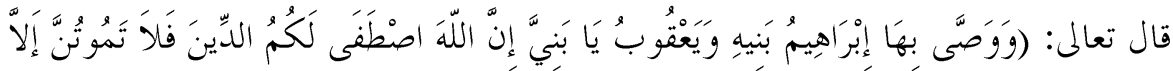

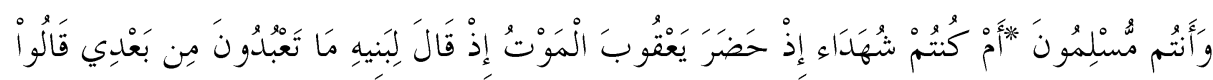

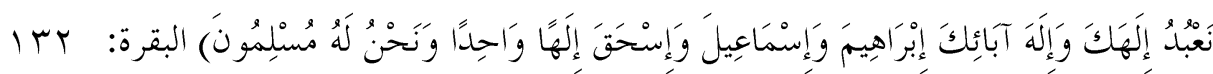

قال تعالى في هاتين الآيتين أي وصاه على الملة، وهي الإسلام لله تعالى (إذ قال ره اسلم أي

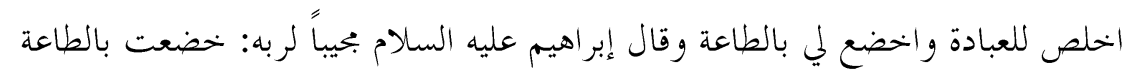
وأخلصت العبادة، لمالك جميع الخلائق ومدبرها) (50) وهي قوله تعالى: (وَوَصَّى بِهَا إبْرَاهِيمُ بَنيهِ

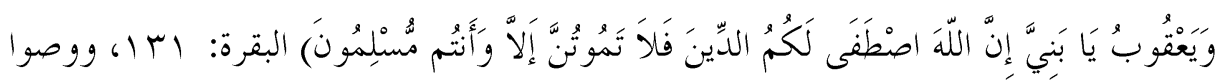

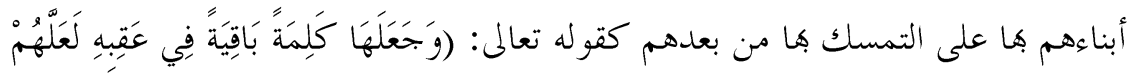

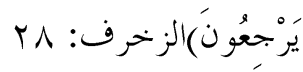

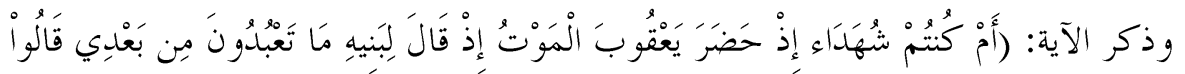

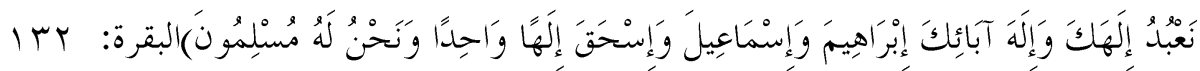

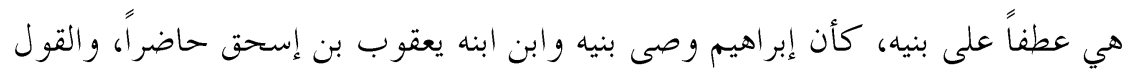
الصحيح أن يعقوب ولد بعد وفاة إبراهيم عليه السلام ولكن البشارة قد وقعت في قوله تعالى:

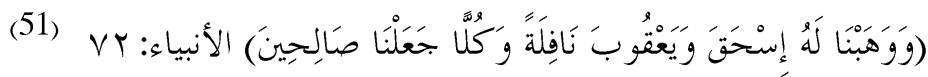

قال تعالى في سورة العنكبوت: \} ووهبنا له إسحاق وجعلنا في ذريته النبوة والكتاب \{.

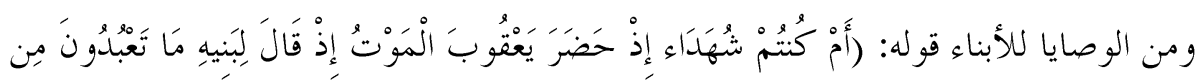

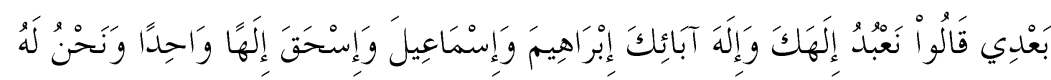

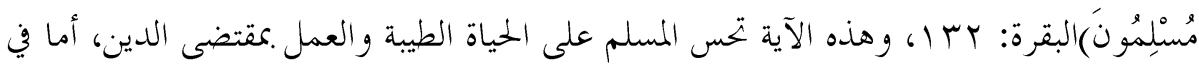
قوله تعالى في وصية يعقوب لأبنائه وصاهم بعبادة الله وحده لا شريك له، فقال هم: \} ما لمال 
تعبدون من بعدي قالو ا نعبد إلهك وإله أبائك إبراهيم وإسحاق ج وهذا من باب التغلب وقوله

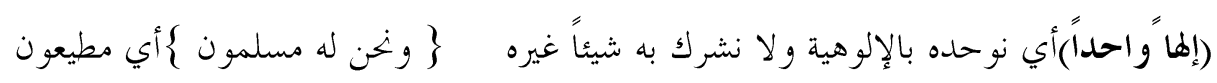
خاضعون و الإسلام هو ملة الأنبياء قاطبة و إن تنوعت شر ائعهم و اختلفت مناهجهم، قال تعالى:

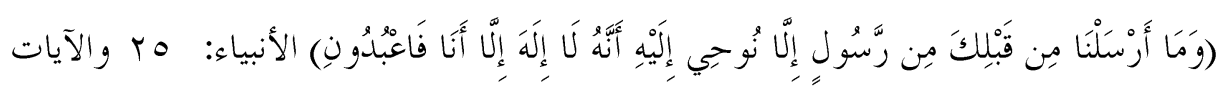
في ذلك كثيرة والأحاديث فمنها قوله (صلى الله عليه وسلم ): (نحن معشر الأنبياء أولاد علات

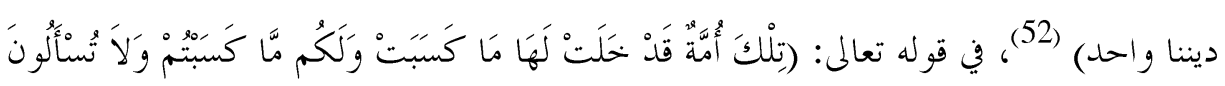

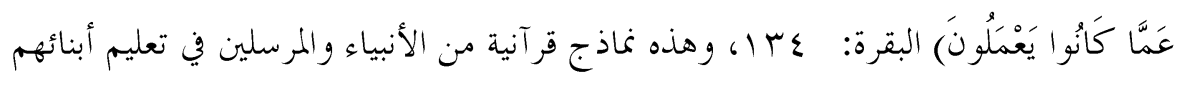
قو اعد الدين وتربيتهم على الأسس الصحيحة والتمسك بها في كل خطوة في حياهم ونسأل الله أن يكون أبناؤنا من يسمعون القول ويتبعون أحسنه.

وهنا سؤال يطرح نفسه عن الوصاية هل هي تربية في أصلها أم هي وسيلة للوصول إلى

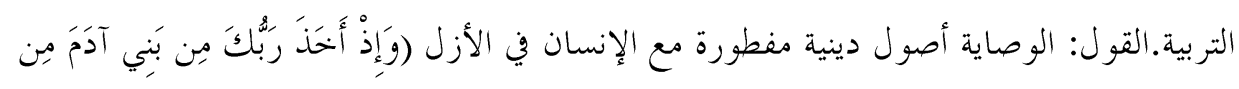

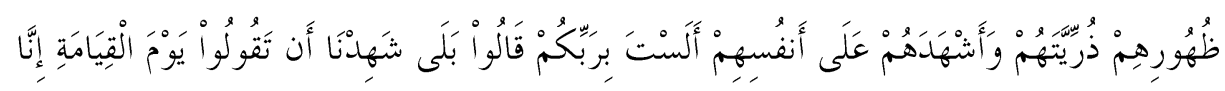

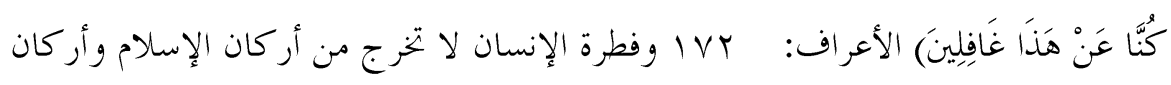
الإيمان، و الوسيلة تكمن في طريقة التبليغ وأسلو به لترقيب والتشويق أو بالترهيب من غضب التهري الله عز وجل مع عدم العمل به. 


\section{المبحث الرابع}

\section{عو امل انحر اف الأبناء ومعالجتها}

في البدء نتحدث قليلاً عن أهمية الأم والأب في التربية بالنسبة للطفل الصغير خاصة والكبير

عامة لا يستطيع الرجل أن يسد مكان الأم ودورها والعكس في التربية وليس دور الأم فقط

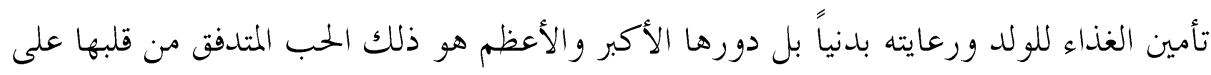

الولد والحنان الذي يشعر به الولد والحنان الذي يشعر فيه الولد بالأمن والسعادة فينمو بدنه

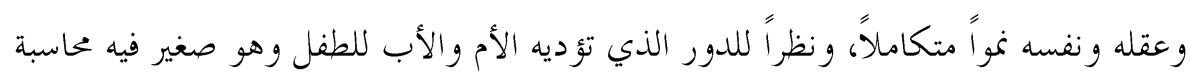

شرعية إسلامية لتربية الابن على أركان الإممان والإسلام ما جاء في الحديث كل إنسان يولد على الفطرة فأبواه يهودانه أو يمجسانه أو ينصرانه، فعلى النساء والرجال رعاية الأبناء على أتم وجهه لأهم مسؤولون أمام الله تعالى قوا أنفسكم وأهليكم ناراً فالتر بية السليمة من أهم دعائم الأسرة

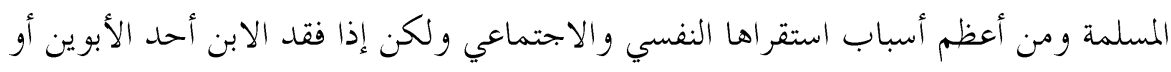
الاثنين معاً سواء كان بالطلاق أو بعدم استقرارهما في الجو الأسري فهذا يؤدي إلى الانحلال والانخراف.

أولا: إذن من أهم عوامل الاخراف للأبناء هو الشقاق بين الزوجين، فالشقاق يؤثر على نفسية الأطفال مما يؤدي إلى انخر افهم عن الأسرة وعن المختمع. (53) واستمرار الشقاق ما بين الأب والأم في أعظم ساعات الاجتماع و الكفاءة، فالولد حين يفتح في البيت عينه ويرى ظاهرة الخصومة أمام ناظريه سيترك حتماً البيت ويهرب من محيط الأسرة إلى رفاق الشوارع وما أدراك ما الشارع ! فسيتدرج معهم على الانحراف ويتدلن معهم إلى أرذل الأخلاق و بالتالي يصبح أداة خطر وبلاء على البلاد و العباد. (54)

و كما أن هذا الخلاف قد يؤدي إلى الطلاق وهو العامل الأساسي للانحراف والتشرد والضياع. 
ثانيا: الخلل من الأبو ين أو أحدهما عندما يقصر في التربية أو ترك التربية أصلاً والانتقال بالأعمال والأسفار و التقصير في التمسك بالجانب الديني والأخلاقي.

ثالثا: ومن الأسباب أيضاً الفراغ، فالوقت أغلى ويجب ألا تترك الأولاد يضيعو أوقاهم في الفساد وعدم استقلال بالطريقة الصحيحة في الطاعة والعبادة والمباحث و المحافظة على الأذكار والانتفاع بالطاعات.

رابعاً: الفقر، وله دور مهم في تربية الطفل تربية حسنة والطفل إذا لم يتوفر له متطلبات الحياة من غذاء و كساء وغيره وينظر إلى ما هو حوله فيجد الفقر والحرمان ومن المؤكد يرجع إلى الخارج للبحث وراء الرزق، فتلتطه أيدي السوء فيعيش في الجمتمع بحرماً خطرا على الأنفس والمال. والإسلام قد حدد للفقراء الإعطاء من بيت المال لكل عاجز.

ومن الأسباب أيضاً اليتم، والولد إذا مات أبوه يفقد الأسوة والقدوة ومعها تسوؤ تربية أخلاقه،ور.ما فسدت معيشته ولقد حث الإسلام على رعاية الأيتام وكفالتهم المادية والتربوية و الأخلاقية والاجتماعية والعاطفية.55) خامسا: الصحبة السيئة من أسباب الانحراف، كثير من المنحرفين يرجع سوء الانخراف لأصدقائهم و أصدقاء السو ء.

سادسا: العولمة لها ايجابيات وسلبيات على الجيل الحاضر وتطرق هذا البحث على الجانب السلبي

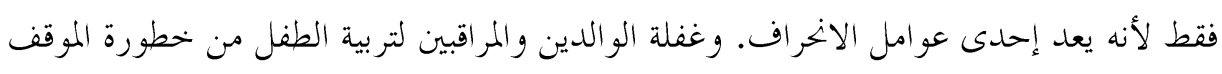
وتمسكهم بالجانب الايجابي فقط. فهو من أهم أسباب الاخرراف على الجيل المعاصر وهي، التي تتسرب على عقول المسلمين لتغيير المفاهيم و الثقافات و العادات والتقاليد والخضارات وصبغ الأفكار بمفهوم غربي. 
و العولمة تعني الاستلاب الثقافي وتدمير الهوية الوطنية وهي خحدعة كبيرة ومؤامرة عظمى للسيطرة الشاملة الكاملة على العالم ليس فقط في الجو انب السياسية والاقتصادية والعسكرية، ولكن أيضاً وهذا هو الأسوأ في مجال الثقافة والقيم والأخلاق. (56)

وعرفها آخر بأن العولمة الآن هي العملية التي تملك آليات التطبيق التي تحول العالم إلى شكل

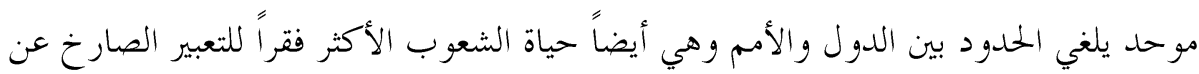

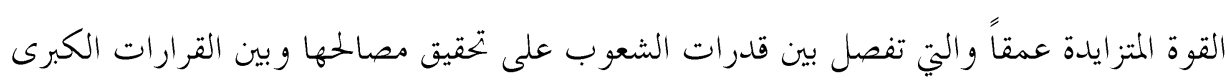

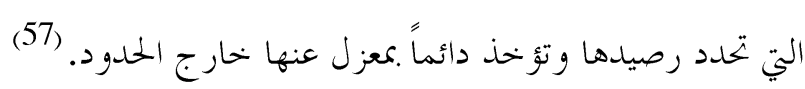

ومفهوم العولمة بشكل عام هو اندماج السوق العالمية في حقول التجارة والاستمار المباشر و انتقال الأموال والقوى العاملة والثقافات والتقانة ضمن إطار من الرأسمالية وحرية الأسواق العالمية مما يؤدي إلى اختراق الحدود القومية وإلى الانحسار الكبير في سيادة الدولة.58) إذن العولمة تعني إزالة الحواجز بين الثقافات والانفتاح عالمياً ليصبح العالم وحدة بإدارة التكنولوجيا وتحول العالم إلى قرية صغيرة فيها وتبادل المعلومات على الفور. و العولمة هي دمار للحضارة و الثقافة الإسلامية وانتهاك حقوق الهوية القومية وتحطم الحلدود الإنسانية في التعامل مع الحياة، وبالأصح هي استيطان يقوم على حساب المقومات الوطنية و القومية وكما أن العولمة هاجم الدين وتريد أن بتعل العالم لا دين له وتنقل فكر الناس بالدنيا و نعيمها الزائف عن الآخرة ونعيمها الدائم.

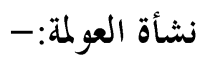
في الواقع أن العولمة لم تنشأ فجأة و لم تلعب فيها تكتيكات المباغتة دوراً، بل كانت طموحاً وأملاً صاحب جميع القوى السياسية والاقتصادية والدينية في تطورها وفي مسيرها التاريخية. (59) 
ويمكننا القول أن العولمة تاريخاً قديماً و بالتالي فهي ليست نتاج العقود الماضية التي ازدهر فيها المفهوم وذاع وانتشر حتى أصبح أحد المفاهيم الرئيسية لتحليل الظواهر المتعددة التي تنطوي عليها العولمة في السياسة والاقتصاد والاجتماع و الثقافة والدين وتسارع استخدام لفظ العولمة في السنوات العشرة الأخيرة وبالذات عقب سقوط الاتحاد السوفيتي ومع هذا فإن الظاهرة التي تسير إليها ليست حديثة بالدرجة التي توحي ها حداثة هذا اللفظ والعولمة ليست حديث للدين لأن الدين كله علم وثقافة وحضارة ربانية إنسانية، والدين الإسلامي صالح لكل زمان ومكان، أما العولمة الآن فركزت على الجوانب الشيطانية وتدمير الأخلاق التي تحفظ الإنسان على الفطرة.

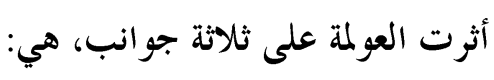
الأثر الثقافي والاجتماعي والاقتصادي.

فالثقافة بلا شك هي أكثر تعقيداً وتشابكاً من الجوانب الأخرى، فالجانب الثقافي فيه الحيوط

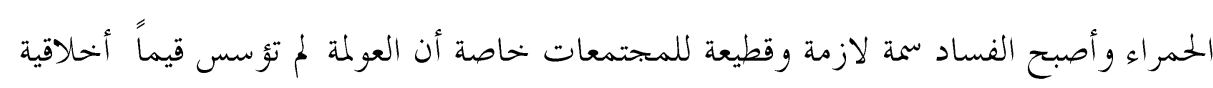
بل عملت على محو القيم وزرع قيم أخرى لا علاقة لها بالدين. (60) و لم بحد ثقافة موجودة إلا في حلقات الرقص والشعر والغناء و القصائد التي تظهر عند المناسبات الوطنية وغابت القصة والمسرح والرسم والمتاحف الوطنية الأثرية، وتصور الواقع العام كما هو من خلال الثقافة الوطنية المتكاملة البعيدة عن حضارة الأمة وتر اثها وتطلق وتطلعاتا نخو (61) (المستقبل

عملت العولمة على تخليص الناس خاصة في بحال الثقافة وأرادوا توحيد الصحافة في جميع الدول خحاصة العربية أن يجعلوا الثقافة غربية وليست لها معنى حتى يتمكنوا من محو الثقافة العربية الموروثة عن الآباء والأجداد التي لا مثيل لها بثقافة ليس ها أي معنى ابتدعا الغرب لكي يلهو هيا الناس عن كثير من الأمور المهمة التي تخص الدين والدنيا.(62) 
والبحتمع لا يمكنه أن يتطور بكعزل عن الجمتمعات الإنسانية وما تمتلكه هذه البحتمعات من قيم وثقافات، فعبر الزمن يحدث التأثير الثقافي علاقات جديدة بين المختمعات قد يكون لها الأثر في تطور القيم أو تبادها لكلا الطرفين المتأثرين إيجابياً وعندما يرفض أي بحتمع أن يأخذ في اعتباره

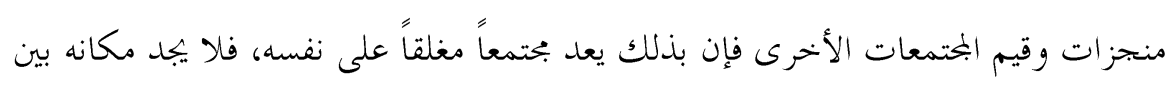
الشعوب في عصر العولمة التي تعتمد العلاقات فيها على تبادل المعلومات(ك3) و وما شكل خطورة علينا نحن المسلمون و لا نعيره اهتماماً أن الغرب يقوم بعمل لجان من أجل

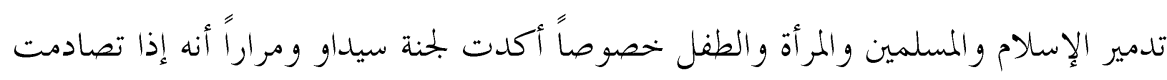
آراؤها حول حقوق المرأة مع الدين والثقافة، فعلى الدين و الثقافة الننحي عن الطريق بل طالبت اللجنة علناً بإعادة تفسير القرآن بطرق تكون مقبولة للجنة، فالأثر الاجتماعي لتحكم العولمة بالشعوب في أدائها فأصبحنا نتبع الغرب حتى في بحتمعهم و بيئتهم التي يعيشون فيها.(64) ومن الآثار الاجتماعية التي خلفتها العولمة نشاط شركات المافيا في نشر المخدرات بأنواعها في البلدان العربية لتحطيم شباب الأمة وجعلها أمة عليلة خاملة وبخحت في ذلك، فاليوم قد أصبح أغلبية الشباب في أعمار صغيرة جداً يعانون من الإدمان. وانتشار الجمعيات الفعالة المنحرفة في البلاد مثل جماعة عبدة الشيطان وهي مؤامرة صهيونية.65) ومن الآثار الاجتماعية الخطيرة التي خلفها الاستعمار بعد الأثر الديني اهيار المبادئ والقيم الأخلاقية، أدت العولمة إلى التخلي عن المبادئ والقيم الأخلاقية الدينية والقومية الأصيلة من أجل الحصول على منافع مادية بدون وجهه حق وتصبح أنواع الفساد المختلفة مهارة أو نشاطاً بينما

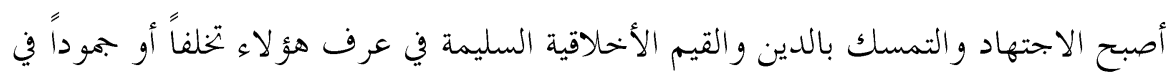
الفكر عكس مضموها الحقيقي، وازدادت الخطورة عندما شب العديد من النشء و الشباب على لى هذه القيم والأفكار المخلوطة مما يؤدي إلى عدم الاهتمام بالعمل و العلم والتعلم والاجتهاد 


$$
\text { كوسيلة للكسب والحصول على الدخول، فيؤدي إلى شيوع قيم الفساد وثقافة حيث يسود }
$$

ومما سردناه عن العولمة بنحد أن هنالك أهدافاً واضحة لها من ضمن تلك الأهداف:

الإلغاء التام للشخصية الوطنية والإقليمية والدينية وصهرها في تلك الشخصية العالمية.

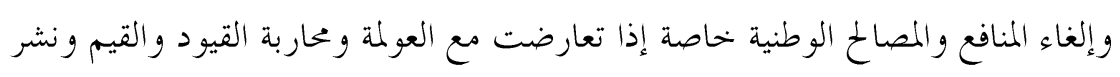
الممارسات الرذيلة وفتح المختمع بالمنكرات و الضغوط على المسلمين بلغة الإرهاب. • هدم اللغة العربية لأن الأساس والر ابط القوي بين المسلمين وأها لغة القرآن.

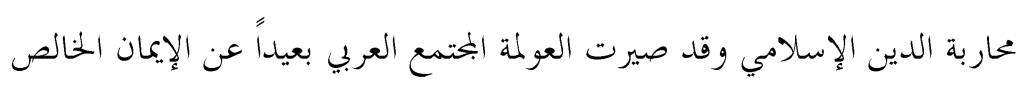
الحقيقي.

تمزق الشعوب وتفتيت الوحدة و وجعل الشعوب تتمرد وتخرج عن السلطة بلا مبرر

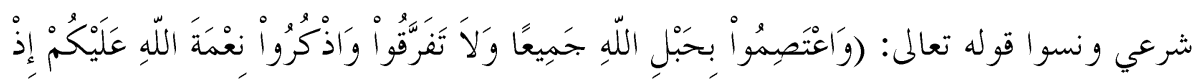

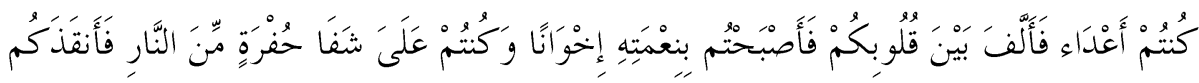

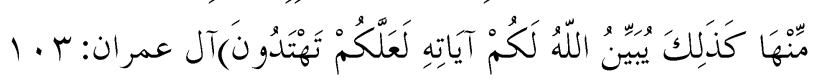
إذن للعولمة وسائل تساعد على الفساد وهي نوعان على الأقل: وسائل مرئية ووسائل

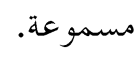
فالوسائل المرئية: كالصور والمحلات العارية وأفلام الجنس والمسلسلات الفاضحة والفيديو والإنترنت وأفلام خليعة وقصص الغرام المثيرة.والسيناريو والكمبيوتر وغيرها، فهي تفسد أخلاق الكبار فكيف بالمر اهقين والأطفال الصغار، فهذا يؤدي إلى الانخراف الأخلاقي. ومن الوسائل المسموعة كأشرطة الغناء والموسيقى التي تحرك الغرائز وعلى هذا يجب على الآباء والأمهات أن يبعدوها من بيوقم المسلمة وعليهم أن يتقوا الله في أنفسهم وأولادهم لأفم ثمرة الحياة والمسؤولية أمام الله تعالى.(68) 
وعلى هذا أقول على الداعية أن يو اجه الهجمة الشرسة ضد الأسرة بوعي وثبات وعليه أن يعزز دورها باعتبارها المؤسسة الأولى وأها خط أمان للقيم الفاضلة والأخلاق النبيلة، وكما عليه أن يعالج قضايا التفكك الأسري بالقيم الحسنة والفضائل الجمة وهي تحتاج إلى تحريك واستثمار لهذه القيم لإصلاح أمتنا ووطننا وهضتنا فعلى الدعوة أن تربط بين القيم والأخلاق وبين العبادة و السلو ك. النتائج

مسؤولية المرأة المسلمة كبيرة نخو بناء جيل واعد ينطق بالحق ويتحمل مسؤولية الأمة

المسلمة.

الخحبة في الاحترام المتبادل بين الزوجين لها دور مهم في تماسك الأسرة وتربية جيل صحيح معاف من الانخر اف وأنو اعه. الوحي الإلهي هو الذي وضع أصول المنهج التربوي وحدد أساسياته من الوحدانية وبر الوالدين والأمر بالمعروف و النهي عن المنكرئ...الخ.

نشر الدعوة الإسلامية يتطلب الاستفادة من وسائل الإعلام الحديثة بالطريقة الصحيحة لكي تؤثر في تربية الجيل الإسلامي المعافي. العولمة تحمل في طياتا العديد من الجوانب فيها الأشياء السلبية المدمرة و كذلك الأشياء

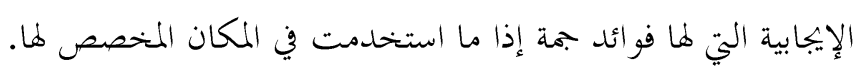
للتربية اثر واضح في كل مراحل نمو الفرد.

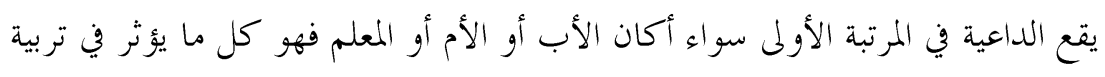
الطفل إسلامياً فهو الداعي المربي. 


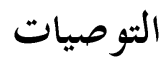

1/ على المربين أن يقتدوا بالمنهج الإسلامي في التربية وألّا ينشغلوا بالدنيا ويتركوا تربية أولادهم

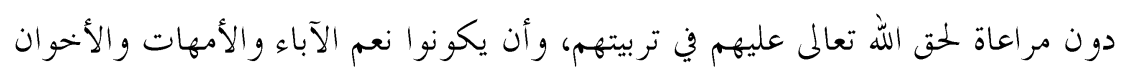
والأصدقاء.

2/ عدم رفض العولمة لأنه لا يمكن أن يعيش المسلمون في معزل عن العالم ولكن يجب أن يأخذوا الجو انب المفيدة ويسخروا طاقاقم وجهودهم في صد الجوانب المدمرة.

3/ صحوة الدعاة والمفكر ين وانتباههم لما يميط هم من أخطار حول الإسلام والمسلمين و والشباب.

/4/ إدخال عقيدة راسخة في قلب الأبناء وذلك باستخدام الأدلة البديهية الفطرية للإقناع

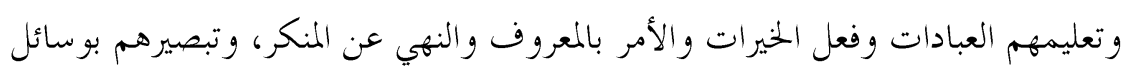
الملحدين لنشر الإلحاد وانخر اف الأمة المسلمة عن غاياها.

5/ لابد للداعية من الاستفادة من علوم التربية وخبرات المربين وتجاربمم العديدة والمتنوعة في

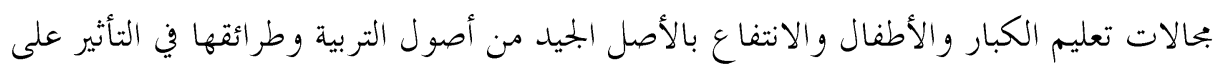

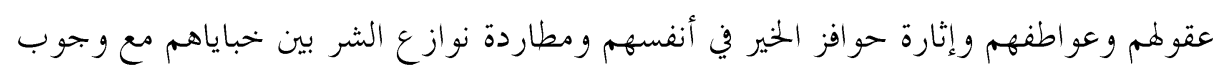
الاحتراز من الزعات المدامة والشطحات المتطرفة في الفلسفات الحديثة المعاصرة. 


\section{فهرس المصادر والمراجع}

القران الكريح.

أ/ البخاري، كتاب الأحكام، باب قول الله تعالى وأطيعوا الله وأطيعوا الرسول وأولى الآمر

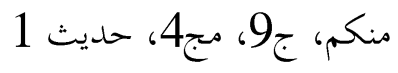

1. المصباح في غريب الشرح الكبير، أحمد بن محمد علي الفيومي،. المكتبة العلمية، بيروت،

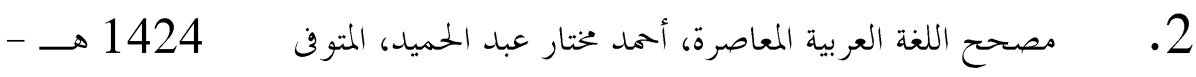

2008م، عدد الأجزاء 314 بتسلسل ج1، ص116. عالم الكتب، ط1، الأجزاء 314.

3. مختار الصحاح، زين العابدين أبو عبد الله محمد بن أبي بكر بن عبد القادر الحنفي

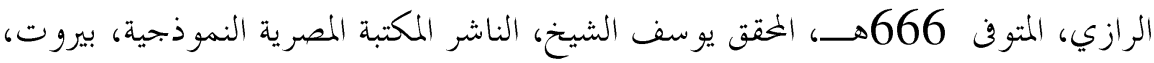

$$
\text { صيدا، ط5، 1420هـ - 1499، 1999م، جن }
$$

4. النهاية في غريب الحديث والأثر، بحد الدين أبو السعادات المبارك محمد ابن عبد الكريم،

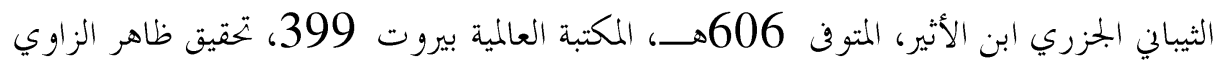

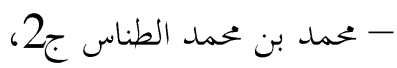

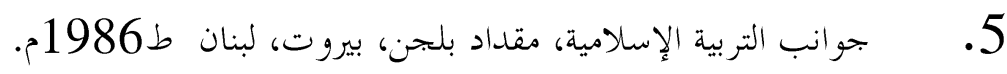

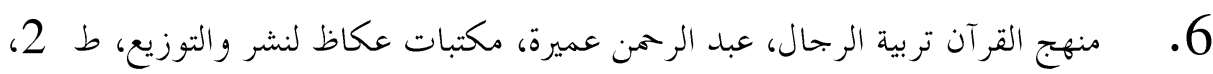
1981

7 . مفاهيم ومبادئ تربوية، الصباغ

8. لسان العرب، محمد بن مكرم أبو الفضل، جمال الدين بن منظور، المتوفى 711هـــ،

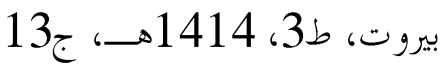

9. كتاب التعريفات، الجرجاني، المتوف 816هــ، دار لكتب العلمية بيروت لبنان، ط1،

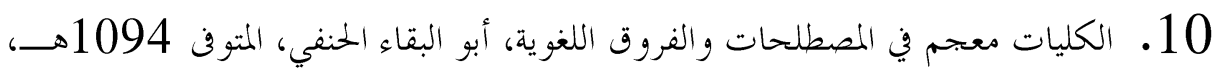

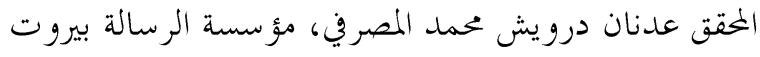




$$
\begin{aligned}
& \text { 11 ـ المصباح المنير في غريب الشرح الكبير. } \\
& \text { 12. مدخل إلى علم الدعوة، محمد أبو الفتح البيانوين، فكر وزارة الأوقاف والشئون }
\end{aligned}
$$

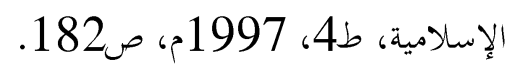

$$
\begin{aligned}
& \text { 13. صحيح مسلم، كتاب الإيمان، باب قول البي صلى الله عليه وسلم بني الإسلام على } \\
& \text { 14. موطأ مالك، كتاب حسن الخلق، باب ما جاء في حسن الخلق، الحديث } 8 \text { ماب } \\
& \text { 15. المسند المستخرج على صحيح مسلم لأبي نعيم، كتاب الإيمان، باب في الإيمان، رقم } \\
& \text { الحديث } 74 . \\
& \text { 16. الرسول المعلم، يوسف القرضاوي و مكتبة وهبة 1425هـ - 1999م، ط 2، } \\
& \text { القاهرة } \\
& \text { 17. تربية الطفل من القرآن والسنة، سيد أحمد جمعة، ط1، 1428هـ - 2007م. }
\end{aligned}
$$

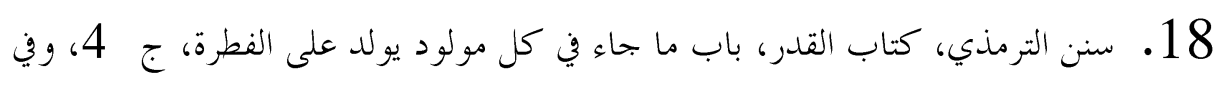

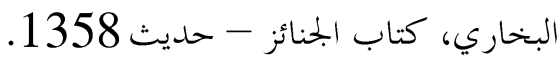

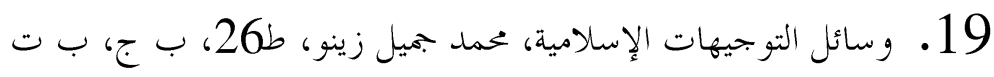

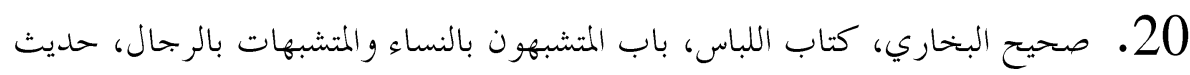

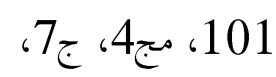

$$
\begin{aligned}
& \text { 21. الدور التربوي للو الدين، حنان عطية الجههن، الملك فهد الوطنية، ط1، 2001م } \\
& \text { 22. سنن ابن ماجه، كتاب الجهاد، باب الرمي في سبيل الله، حديث رقم } 2813 . \\
& \text { 23. التربية الإسلامية بين الأصالة والمعاصرة، عبد الغني النووي، دار الفيحاء، ط 1 1، بن تبن، } \\
& .106 \\
& \text { 24. موطأ مالك، كتاب حسن الحلق، باب ما جاء في حسن الخلق، رقم3. } \\
& \text { 25. سنن الترمذي، أبواب البر والصلة، باب ما جاء في حق الجوار، حديث رقم } 2007 . \\
& \text { 26. أصول التربية الإسلامية، عبد الرحمن النحلاوي، دار الفكر، دمشق، ط1، 1997م } \\
& \text { 27. ، ، عبد الخالق ثروت، ط1 1990م 1900. } \\
& \text { 28. ع عدنان درويش، محمد المصري، مؤسسة الرسالة، بيروت. }
\end{aligned}
$$




$$
\begin{aligned}
& \text { 29. الخصائص العامة للإسلام، يوسف القرضاوي مكتبة وهب القاهرة، ط4، 1989م. } \\
& \text { 30. مدخل إلى علم الدعوة، محمد أبو الفتح البيانوني، وزارة الأوقاف والشؤون الإسلامية، }
\end{aligned}
$$

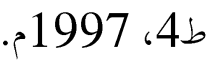

$$
\begin{aligned}
& \text { 31. عقوق الوالدين، محمد بن إبراهيم الحملد، وزارة الشؤون الدينية والأوقاف والدعوة } \\
& \text { و والإرشاد، ط2، 1423هـ } \\
& \text { 32. الأمر بالمعروف والنهي عن المنكر، ابن تيمية، دار البحتمع جدة ط2، 1403هـه، }
\end{aligned}
$$

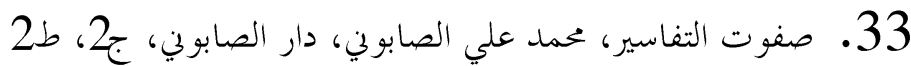

$$
\begin{aligned}
& \text { 34. منهج القرآن في تربية المختمع، عبد الفتاح عاشور، دار المكتبة الخاذجي، مصر، ط 1979، } \\
& \text { 1979م } \\
& \text { 35. فلسفة التربية الإسلامية في القرآن الكريه، علي خليل أبو عينين، مكتبة إبراهيم علي، } \\
& \text { المدينة المنورة، ط3 } \\
& \text { 36. لزهد ولاحمد بن حنبل، قصة نوح عليه السلام، دار الكتب العلمية، بيروت، لبنان، } \\
& \text { ط1، 1999 1990، رقم } 285
\end{aligned}
$$

37. تفسير الطبري، جامع البيان في تأويل القرآن، أحمد محمد شاكر، مؤسسة الرسالة، ط 11، 2000

38. تفسير القرآن العظيم، ابن كثير، المتوف 774هــ، ج1، 1983م، دار المعرفة بيروت 39. مسلم، كتاب الفضائل، باب فضائل عيسى عليه السلام، ج 1، جل، ج13 مسؤولية الأب

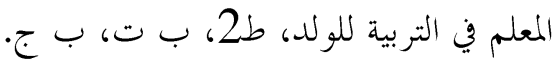

40. تربية الأولاد في الإسلام، ناصح علوان، بيروت، ط4، 1981م، جـ 41. مواجهة العولمة، زكريا بشير إمام، مركز قاسم للمعلومات والخحدمات، ط1 2000م 42. الثقافة العربية في زمن العولمة، أحمد بجدي حجازي، ط1، 2003 2003، دار قباء للنشر 43. العولمة قدر أم اختيار، الطيب على عبد الرحمن وزارة الثقافة والسياسة، ط1، 2002م، الخرطوم 44. العولمة، محسن أحمد الخضري، ط1، 2004م 


$$
\begin{aligned}
& \text { 45. الثقافة والعولمة، سعيد هارب، ط2000، 120، دار الكتاب الجامعي }
\end{aligned}
$$

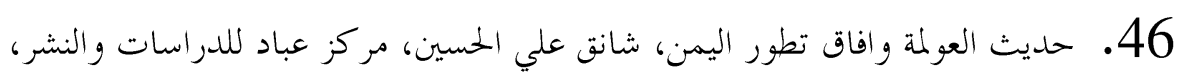

$$
\begin{aligned}
& \text { ط2، } 2003 \\
& \text { 47. التصنيف القيمي للعولمة، عقيل معسن عقيل، ب ط 2003 }
\end{aligned}
$$

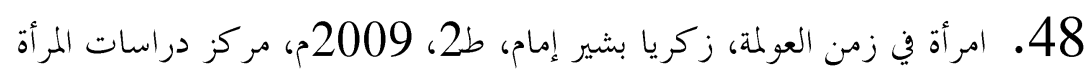

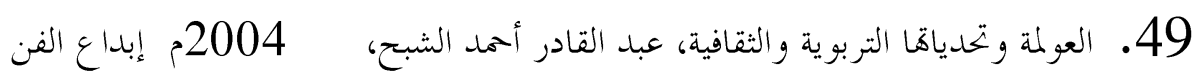

$$
\begin{aligned}
& \text { للطباعة } \\
& \text { 50. العولمة والجدال الدائر حولها، فلاح كاظم الخسن، ط1، 2002م، دار الوراق للطباعة } \\
& \text { والنشر } \\
& \text { 51. العولمة والقيم، حيدر حميد الرهوي، ط2، 2008م، دار علاء الدين للنشر. }
\end{aligned}
$$

